\title{
FIRM SIZE AND SUSTAINABLE PERFORMANCE IN FOOD SUPPLY CHAINS: INSIGHTS FROM GREEK SMES
}

\author{
Michael Bourlakis ${ }^{\mathrm{a}}$, George Maglaras ${ }^{\mathrm{b}}$, Emel Aktas $^{\mathrm{c}}$, David Gallear $^{\mathrm{c}}$, Christos Fotopoulos $^{\mathrm{d}}$ \\ a- Cranfield School of Management, Cranfield University, Cranfield, Bedford MK430AL, UK \\ b- Institute for Retail Studies, University of Stirling, FK94LA Stirling, Scotland, UK \\ c- Brunel Business School, Brunel University, Kingston Lane, UB8 3PH Uxbridge, UK \\ d- Department of Business Administration in Food and Agricultural Enterprises, University of Western \\ Greece, 2G.SeferiStr., Agrinio30100,Greece
}

\begin{abstract}
This paper analyses sustainable performance differences within the Greek food supply chain and provides numerous statistical comparisons of its key members (growers, manufacturers, wholesalers and retailers) with respect to firm size. In an attempt to fill a gap in the relevant literature, we examined micro, small and medium-sized firms against a set of sustainable performance measures and we employed survey research using a sample of 997 firms operating in the Greek food supply chain. Key informants evaluated their firms based on sustainable performance measures (consumption, flexibility, responsiveness, product quality and total supply chain performance). The results were analysed using ANOVA. The findings identify the Greek food supply chain members who over-perform or underperform in relation to size. These include small growers, wholesalers, retailers, medium-sized manufacturers and wholesalers, micro manufacturers and retailers. Specific reasons are provided for these sustainability performance differentials including the role of locality as well as the asset and resource intensity of some operations (e.g. manufacturing). Another key finding relates to small firms which are the top performers in terms of sustainability performance measures especially in the areas of flexibility and responsiveness. Members of this chain also underperform in the product conservation time measure, irrespective of size, and we highlight the urgent need for this to be addressed. Findings of this paper will prove useful for food SMEs and policy makers planning to introduce specific sustainability incentives related to firm size and to the food chain.
\end{abstract}




\section{Introduction}

Sustainable supply chain management (SCM) is "the strategic, transparent integration and achievement of an organisation's social, environmental, and economic goals in the systematic coordination of key interorganisational business processes for improving the long term economic performance of the individual company and its supply chains" (Carter \& Rogers, 2008). Carter \& Rogers (2008) posit that a deliberate long-term strategy combining environmental and social aspects of sustainability, which extends beyond a firm's boundary with economic objectives, helps firms to mobilise those supply chain activities that directly support sustainability. These can, in turn, create a pervasive and less imitable set of processes and a basis for competitive advantage for these firms and associated chain members (Carter \& Dresner, 2001). As Flint \& Golicic (2009) observe, not surprisingly, sustainability has received increasing attention in the literature as a potential differentiating competency for supply chains, and has become an inescapable priority for firms worldwide (Porter \& Kramer, 2006). Performance measurement systems that include sustainability considerations can be a driver for sustainability performance improvement without sacrificing other aspects of operating performance (Angell \& Klassen, 1999).

The food industry has many impacts on sustainability, and vice versa (Maloni \& Brown, 2006). Discerning customers are increasingly interested in the origin of food products, what they contain and who made them. In addition, policy makers, legislators, influence groups and financial institutions are progressively placing pressure on firms to report on sustainability performance (Keeble, et al., 2003; Kolk, 2004). It is worth stressing that, in Europe, the food sector has a significant role; the combined agricultural and food sector forms an important part of the EU economy, accounting for 15 million jobs (8.3\% of total employment) and $4.4 \%$ of GDP (Moussis, 2013). In Greece, where the empirical work took place, the food sector constitutes $25 \%$ of the GNP and it is the leading sector amongst all industrial sectors in terms of GNP contribution (Notta et al., 2010). It is clear that the food sector, like many other sectors such as automotive (Nieuwenhuis et al., 2012), electronics and appliances (Kumar \& Putnam, 2008), textile and apparel (Wu et al., 2012), has reached a juncture where customer and other stakeholder concerns about sustainability performance now need to become integrated with other dimensions of value when managing supply chains (Angell \& Klassen, 1999). Small and medium-sized enterprises (SMEs) are not immune from these competitive 
pressures (Moore \& Manring, 2009), particularly given that their total (cumulative) impact on sustainability is high (Gadenne et al., 2008; Worthington, 2012).

Sustainability aside, SMEs have been found to be less able to harness the benefits of SCM and face greater obstacles when adopting SCM practices such as vendor managed inventory (VMI), electronic data-interchange (EDI, simulation and scenario analysis and e-purchase solutions than their large firm counterparts, and clear differences in performance between SMEs and large firms have been observed (Vaaland \& Heide, 2007). Banomyong \& Supatn (2011) for example, tested a tool for SME supply chain performance measurement on SMEs in Thailand and found that the SMEs only performed better than a benchmark large firm in one (delivery cycle time) out of the 26 measures. It is therefore not surprising that many SMEs have also not progressed in the adoption and development of sustainable supply chain practices (Hassini et al., 2012). This, in part, is attributed to the upfront cost of greening (Hassini et al., 2012) and the short-term cost investment to effect changes, such as the cost of implementation and compliance with environmental regulations, the cost of sustainable design and construction, the capital investment cost in low energy, logistics-related alternatives including ventilation, heating and lighting (Revell \& Blackburn, 2007), in addition to insufficient time, training and managerial expertise to invest in environmentalism (Worthington, 2012). However, it is also attributed to a lack of sustainability performance evaluation (Biondi et al., 2000). In addition, it is widely recognised that SMEs often do not have the time, resources or information required for performance measurement, or the skills required to collect and meaningfully evaluate such information. Hudson et al.'s (2001) study comparing theory and practice in SME performance measurement systems revealed significant gaps in the utilization of strategic performance measurement systems due to the resource intensive nature of performance measurement. In Russo \& Tencati's (2009) study of Italian SMEs it was concluded that no attention was paid to issues relating to the evaluation and reporting of sustainability performance. The result is that SMEs do not have a clear understanding of their own sustainability performance, which then becomes a barrier to progress in sustainability implementation. In this respect, the status of the extant literature provides limited help.

Although the literature is rich on supply chain performance measurement in general (e.g. Beamon, 1999; Gunasekaran, et al., 2004; Theeranuphattana \& Tang, 2008; Hofmann \& Locker, 2009; Akyuz \& Erkan, 2010; Elgazzar et al., 2012), there is a scarcity of research 
papers when more specific contexts, such as SMEs, are considered. This gap is confirmed in recent work by Bititci et al. (2012) who conducted a literature review and stressed that further challenges in relation to performance measurement include performance measurement in SMEs, and indeed sustainability issues in performance measurement. Islam \& Karim (2011) is one of the few recent studies that examined supply chain performance measurement in SMEs. They found that there are significant differences in the strategic approach of SMEs and large firms when manufacturing performance is measured.

Furthermore, while the literature on various aspects of sustainability strategy creation in SMEs (e.g. Gadenne et al., 2008) and/or food supply chains (e.g. Dieu, 2006; Cox et al., 2007; Jamsa et al., 2011) has recently started to develop, a careful examination of the literature indicates only a handful of contributions that have specifically addressed sustainability performance measurement in supply chains in the context of SMEs (Gunther \& Kaulich, 2005; Lee et al., 2012), and none in the context of SMEs in the food supply chain. Gunther \& Kaulich (2005) proposed an eight step environmental performance measurement tool identifying broad impact categories such as waste and depletion of resources, but not specific sustainability measures. Lee et al.'s (2012) study focused on SMEs examining green SCM practices as opposed to performance measures.

Furthermore, just as there are differences between SMEs and large firms, so there are differences between micro, small and medium-sized firms. The smaller the firm's size (i.e. the closer the size of a firm is to that of micro firms), the greater the incidence of a resultoriented culture, patronage and owner-managers at the helm, particularly in very small family-run businesses (Sharma, 2004; Ghobadian \& Gallear, 1997). Hausman (2005) found that the smaller firms often employ individuals based on familial relationships rather than skill set and competence, and that this can affect managerial ethos and outlook (Ghobadian \& Gallear, 1997). This is important because it has implications both in terms of the implementation of practices, such as those supporting sustainability, and in terms of the performance derived. The study of Russo \& Tencati (2009) on corporate social responsibility practices found that micro, small and medium-sized enterprises showed different managerial approaches and responsible behaviours. This important finding led them to call for more research investigating the patterns that differ within the SME category for prevalent management issues, such as sustainability. However, to date, research on firm size differences has almost exclusively focused on SMEs versus large firm experiences (e.g. Vaaland \& 
Heide, 2007; Banomyong \& Supatn, 2011). We have also been unable to find any research that has addressed this important emergent research need identified by Russo \& Tencati (2008) in the context of sustainability performance measurement or food supply chains.

The preceding arguments indicate that a major gap exists in the literature for our understanding of sustainability performance measurement in supply chains in the context of SMEs in the food supply chain, and in our understanding of how micro, small and mediumsized firms themselves differ in performance. Our work addresses this shortcoming by investigating sustainability performance, analysing the effect of firm size at SME level (micro, small and medium) on various appropriate measures developed through a careful review of sustainability measures for food supply chains found in the literature. This approach ensures that our evaluation of sustainability performance is both context-specific to SMEs and uses a defined set of measures that help to ensure that meaningful comparisons can be made (Kolk, 2004). It helps to ensure that the measurement framework reflects the objectives of SMEs in the food chain, which are the focus of this paper (Aramyan et al., 2006). Differences in sustainability performance need to be examined in order for supply chain members to judge their sustainability contribution and identify where improvement is needed. In this paper, we seek responses to the following research questions:

1. How do micro, small and medium-sized members (i.e. growers, manufacturers, wholesalers, retailers) of the Greek food chain perform in key sustainability measures?

2. Are there any differences in the sustainability performance of the Greek food chain with respect to SME firm size?

Given that our empirical work examined Greek food SMEs, we need to highlight the fact that, in general, Greek SMEs have some unique characteristics compared to the average European Union's SMEs. Micro firms represent $96.6 \%$ of the total Greek firms while the EU's average is $92.2 \%$ (Small Business Act, 2012). They also account for $56.6 \%$ of total employment and $39.9 \%$ of value-added in comparison with the EU average of $29.7 \%$ and $21.2 \%$ respectively (Small Business Act, 2012). The average number of employees in a Greek SME is significantly lower (2.75) than the EU average (4.22) (Small Business Act, 2012; Wymenga et $a l ., 2012)$. Hence, the typical Greek SME is smaller than the average EU SME and, in the Greek food sector, $90 \%$ of the production and processing businesses are SMEs (Lambrinopoulou \& Tregear, 2011). Finally, in accordance with the definition of SMEs from the European Commission (European Commission, 2005), both the number of fulltime 
employees and annual turnover were taken into account in this work to determine the classification of firms in terms of size. Subsequently, the micro category included firms employing less than 10 persons and with annual turnover or annual balance sheet totalling no more than $€ 2$ million. The small category included firms employing less than 50 persons and with annual turnover or annual balance sheet totalling no more than $€ 10$ million. In the medium-sized category, we included firms with less than 250 employees and with annual turnover no more than $€ 50$ million or annual balance sheet totalling no more than $€ 43$ million (European Commission, 2005).

In the following sections, we provide an overview of the key sustainable performance measures in relation to food chains focusing on SMEs, the methodology employed in the empirical work and an analysis of the findings. In the remaining two sections, we provide a discussion of the major findings, the conclusions and the key managerial, policy and research implications emanating from this work.

\section{Sustainability performance measures for food chains}

In the context of the food supply chain, we have adapted a performance measurement framework widely used in the supply chain literature (Aramyan et al., 2007; Shepherd \& Gunter, 2006). This framework is advantageous because it enables us to take into account the characteristics of seasonality in production, product safety and sensory properties found in food chains (Aramyan et al., 2007). The framework allows chain-wide measurement and accommodates the inclusion of non-financial measures which are important in the sustainability context (Shepherd \& Gunter, 2006). The framework we used comprises five categories (Table 1); consumption, flexibility, responsiveness, product quality and total supply chain (based on Aramyan et al., 2007 and Carter \& Rogers, 2008). Within this framework, we have identified and classified a total of 18 sustainability measures relevant to food industry supply chains identified from the literature contributions which are shown in the third column of Table 1. In the remainder of this section, each category of measures is explained. 
Table 1 Sustainability supply chain performance measures

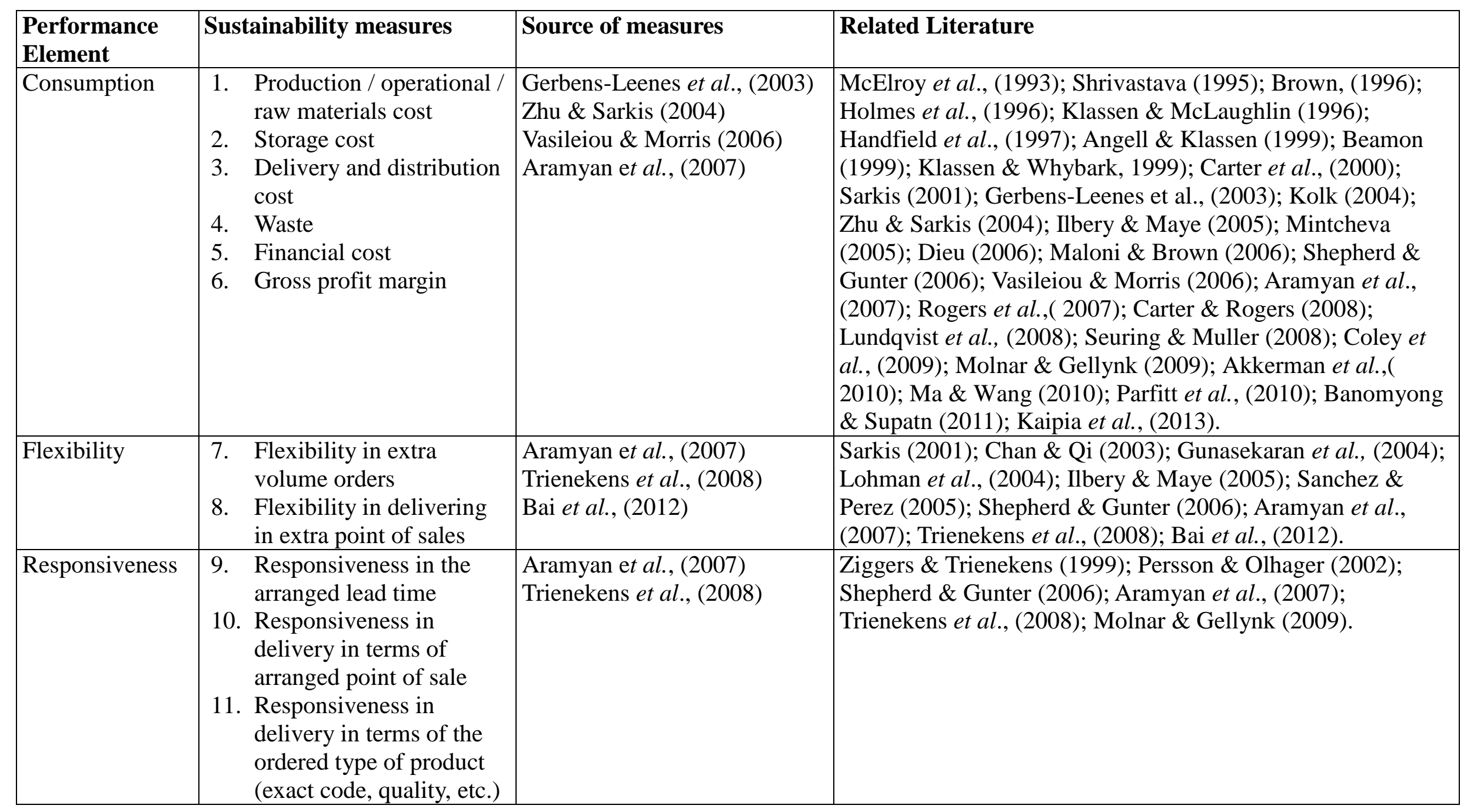




\begin{tabular}{|c|c|c|c|}
\hline $\begin{array}{l}\text { Performance } \\
\text { Element }\end{array}$ & Sustainability measures & Source of measures & Related Literature \\
\hline $\begin{array}{l}\text { Total supply } \\
\text { chain }\end{array}$ & $\begin{array}{l}\text { 17. Firm's perception of its } \\
\text { own supply chain } \\
\text { performance } \\
\text { 18. Firm's perceptions of } \\
\text { market opinion regarding } \\
\text { its supply chain } \\
\text { performance }\end{array}$ & $\begin{array}{l}\text { Aramyan et al., (2007) } \\
\text { Carter \& Rodgers (2008) }\end{array}$ & $\begin{array}{l}\text { Complementary performance measures to those identified in } \\
\text { the literature, which were introduced by the researchers in } \\
\text { parallel with Aramyan et al., (2007) and Carter \& Rodgers } \\
(2008) \text {. }\end{array}$ \\
\hline
\end{tabular}


Firms need sustainability measures that are relevant and context specific. The context of this research was twofold: food supply chains and SMEs. It was therefore important that the choice of sustainability measures in our research reflected the food supply chain and SME contexts, and in this respect, we were cognizant of the following requirements/constraints recommended by Gerbens-Leenes et al. (2003) for measuring sustainability in food production systems: (i) that the measures provide relevant information about the sustainability of the system, (ii) that reliable and accurate measurement is possible, (iii) that the data are available and (iv) that the measures can inform management choices and help to optimize production.

Whilst large firms often have the resources and technical budgets to develop and implement sophisticated performance measurement systems, SMEs efforts continue to be hampered by resource limitations (Wagner et al. 2003, cited in Vaaland \& Heide, 2007). This view is widely shared in the sustainability literature (e.g. Banomyong \& Supatn, 2011; Gunther \& Kaulich, 2005; Biondi et al., 2000). Banomyong \& Supatn's (2011) research on developing a supply chain performance tool for SMEs revealed that SMEs need a limited set of measures that pertain to data that is readily available or easily accessible. Gunther \& Kaulich (2005) noted the comparatively much greater difficulties that SMEs face in the collection of data pertaining to environmental sustainability (Biondi et al., 2000). They advised focusing on data already being collected by the SME and advocated priority be given to raw materials, energy consumption and waste, which are particularly relevant to food chains.

To this end, the first group in our framework comprised measures relating to consumption. For sustainability, reducing consumption is an important contributor. Sustainability is a globally collective goal. Reaching a point where sustainability has been achieved is not something that any single firm can achieve on its own. Reaching a point where sustainability has been achieved, that is, according to sustainability's definition, when globally, collectively, we have reached a point where there is 'enough, for all, forever' (Murray et al., 2012), is a point to which the collective efforts of all facets of society engaged in production and consumption need to contribute. However, inevitably, the efforts and their outcomes will vary from one actor to another. Accordingly, individual firms can only strive to contribute as best they can towards sustainability. One important measure of this contribution is their own level of consumption, and hence it is vital that measures of consumption are part of their appraisal of their sustainability performance (Zhu \& Sarkis, 2004). 
Sustainability advocates that unless resource use is curbed, modern society risks collapse through over-exploitation of the available resources (Murray et al., 2012). Sustainability in food supply chains addresses how a firm can avoid depleting resources, or otherwise reduce its ecological footprint, while at the same time maintaining economic viability. Measuring sustainability performance in the SME context therefore, requires the inclusion of measures that can represent both consumption and expenditure (Zhu \& Sarkis, 2004), in conjunction with profitability (Vasileiou \& Morris, 2006). In this SME context therefore, within this first category, we adopted consumption-based measures of expenditure (costs) to meet the requirements as proposed by Gerbennes-Leenes et al., (2003). In essence, sustainability is comprised of the triple bottom line thinking: economy, environment and society (Gimenez et al., 2012). As the firms reduce their consumption, and as they reduce waste, they become more sustainable.

Production/operational/raw materials cost is a measure of the SME's direct internal resource consumption in making the product. A central principle of sustainability is the deployment of production processes and resources (raw materials and labour) in a manner that enhances total environmental and socio-economic welfare (Angell \& Klassen, 1999). The food supply chain's production processes can have a significant negative impact on sustainability if not designed effectively and managed efficiently (Shrivastava, 1995; Angell \& Klassen 1999). Conversely, well designed production and delivery processes incorporating the latest environmental technologies can reduce total operating costs (Angell \& Klassen, 1999). Labour can also form a significant element of resource consumption in production within food supply chains. Production and operational costs therefore reflect the extent of the firm's achievement in deploying less resource-intensive and hence more sustainable farming techniques and/or processing technologies (Maloni \& Brown, 2006).

Delivery and distribution costs are a measure of both energy consumption in making the food product available to subsequent chain members and of responsible logistics management. Both have emerged as critical issues in food supply chain sustainability in recognition of the ever increasing 'unit price' of delivery and distribution (Carter et al., 2000; Maloni \& Brown, 2006). Delivery and distribution costs reflect the extent of 'scale and spread' of a firm's logistics operation. Responsible logistics management seeks to minimise 'scale and spread' through for example sourcing inputs locally, sourcing its total requirements from fewer suppliers and targeting and marketing to a more local customer base, and will be reflected in 
reduced delivery and distribution costs. Reducing what has become known as 'food miles', namely the distance travelled from grower/breeder to end-user, in turn has a positive effect on reducing fuel consumption and carbon emissions (Maloni \& Brown, 2006). It is clear that reducing 'food miles' has become a key objective of governmental transportation policy (Gerbens-Leenes et al., 2003). The success of SME's attempts to create shorter, more local food supply chains (Ilbery \& Maye, 2005) through their location and route planning systems and through joint planning efforts with other chain members (Seuring \& Muller, 2008) will be evident through their measurement of delivery and distribution costs.

Storage costs are also an important measure of energy consumption in making the food product available in a fit-for-purpose condition to other chain members and customers. Storage costs are a measure of resource consumption that is incurred in part because the product is 'idle' in the food supply chain, and it is primarily for this reason that it is considered separately from the production and delivery/distribution consumption measures discussed previously. Storage costs associated with ageing processes are an unavoidable necessity for many members of food supply chains (Coley et al., 2009). Short term bulk cold storage of the product to preserve its condition, maximise subsequent shelf life and minimise perishability is to some extent also a necessity, however in sustainability terms, bulk cold storage costs represent an 'extra' non-value adding component of resource consumption. This consumption is in fact only needed to prevent the finished product from becoming waste because other mechanisms that would place the product with the customer sooner are absent. As such, the success of food supply chain members' efforts to increase their stock turns, thereby reducing their finished product inventory, and hence reduce one of their potentially largest components of energy consumption will be easily and visibly evident to an SME from the expenditure incurred on storage. Lower consumption through reduced storage is particularly salient given that energy use in chilled storage can be very high (Coley et al., 2009).

Waste is one of the most pervasive sustainability issues in food supply chains (Maloni \& Brown, 2006) and minimisation is frequently identified in the literature as a core measure for sustainability in food production (Gerbens-Leenes et al., 2003). According to Parfitt et al., (2010), as much as 50\% is the most frequent estimate of the amount of all food grown that is lost or wasted before and after it reaches the consumer (Lundqvist et al., 2008). Other estimates suggest that over $30 \%$ of certain foods produced worldwide, such as fresh fruits and 
vegetables do not even reach the market (Kader, 2005). Three types of waste are characteristically common in food supply chains: wastewater (typically from cooling and heating processes); solid by-products including rejected raw materials and rejected packaging and process residues; and air pollutants and surplus heat from boilers/heaters (Dieu, 2006). Waste reduction therefore has the potential for significant gains in resource consumption abatement (Sarkis, 2001). Waste measurement and reporting is an essential food chain sustainability measure irrespective of firm size (Kaipia et al., 2013). It provides evidence to the firm and other chain members of the extent to which practices for waste prevention and minimization are being successfully applied (Mintcheva, 2005). Reduction in waste can liberate financial resources for re-investment in new environmental technologies that can help to further minimise waste and that can be adopted relatively quickly and easily in food supply chains, particularly in those echelons that employ continuous operations processes (Angell \& Klassen, 1999).

Financial costs are a measure of resource consumption in the administration of food supply chain operations. It is relevant to sustainability, particularly for SMEs, because it represents expenditure that could otherwise be invested to augment sustainability. It represents expenditure which is likely to be minimised if the firm promotes employee well-being, which in turn is likely to reduce employee turnover (Brown, 1996). Financial costs refer to the overall cost of labour administration and are incurred when administration is needed for recruitment, selection, contracting and severance. Expenditure increases as employee turnover rises. For SMEs, high employee turnover can be a devastating drain on capital. Financial costs are also incurred, for example, through negligence and compensation claims related to employee safety and welfare. Good working conditions for employees, including rights, provisions and protection, and safer warehousing and transportation practices (Brown, 1996; Carter et al., 2007) are likely to improve employee motivation and operations productivity, and reduce absenteeism and employee turnover (Carter \& Rogers, 2008). Accordingly, the extent to which the SME has been successful in implementing responsible employee well-being policy and practice will be reflected in lower overall financial costs (Holmes et al., 1996; McElroy et al., 1993).

As mentioned previously, to these consumption-based expenditure measures it was necessary to add gross profit margin. This was identified by Kolk (2004) as a key sustainability measure given that sustainability performance is also linked to market gains and economic viability 
(Klassen \& McLaughlin, 1996; Handfield et al., 1997). It is a measure of the ability to grow and prosper (Vasileiou \& Morris, 2006), and to provide returns for responsible investment.

Collectively, the consumption-based measures, in conjunction with gross profit margin are important sustainability measures for SMEs because they determine the financial resources available for re-investment in specific areas to further improve sustainability. For example, Klassen \& Whybark (1999) identified process adaptations to change acquisition, production and delivery processes to reduce waste as an important sustainability investment, made possible through the re-invest of savings from reductions in the consumption of raw materials and other transformation process resources. Reducing delivery and distribution costs can enable the firm to invest in 'green logistics' solutions which recognise that consumption through logistics is affected by the mode of transportation, and the combinations of modes of transportation, and which seek to minimise the total consumption (Ilbery \& Maye, 2005). Examples of 'green logistics' solutions include freight conversion to alternative and more sustainable fuels (Rogers et al., 2007) and co-modal freight planning systems (Akkerman et al., 2010). Reducing storage costs can enable the firm to re-invest in the tuning and optimisation (Ma \& Wang, 2010) of that refrigeration that is necessary, for example the freezing of the final product ready for distribution, or the cold storage needed for product ageing purposes. As already noted, reducing financial costs potentially releases financial resource to re-invest in any of the aforementioned areas.

Our second group of measures relate to flexibility, an extensively used performance measure in both the supply chain (Sanchez \& Perez, 2005; Lohman et al., 2004; Chan \& Qi, 2003) and the food supply chain literature (Bai et al., 2012; Trienekens et al., 2008; Aramyan et al. 2007). Flexibility is a measure of the firm's ability to re-route food product within the supply chain in order to avoid waste. It is therefore an essential sustainability measure in the food chain context given the perishability of the food products. This is particularly important in the later stages of the food chain, as losses incurred here are not only the loss of the product itself, but also the loss (i.e. waste) of all the resources devoted to getting the product so far down the chain. As such, two flexibility sustainability measures are particularly important for SMEs operating in food supply chains: flexibility in delivering to extra points of sale, and flexibility in extra volume orders (Ilbery \& Maye, 2005). Waste and fuel consumption can be reduced when the ability to change the output levels of goods produced (Aramyan et al., 2007) and the ability to change planned delivery points are present. As Shepherd \& Gunter 
(2006) argue, flexibility signals to other upstream and downstream members in the chain the firm's ability to deal with changes in demand or supply, and thus their capability firstly to help reduce resource consumption, and secondly to contribute to the provision of products to the end-customers (Gunasekaran et al., 2004). Thus, delivery and volume flexibility directly support other sustainability practices, and enable the chain members to maximise the amount of useable food within the chain, and consequently also to maintain competitiveness (Sarkis, 2001). Furthermore, flexibility is an important sustainability measure in food chains because the ability to re-route and/or alter delivery volumes can potentially offset the losses that may occur due to poor responsiveness, as discussed below.

Our third group comprises three measures that are concerned with responsiveness. Similar to flexibility, they reflect the ability of the chain members to avoid wasted product as it progresses through the food chain, and consequently also to deliver a high customer service (Shepherd \& Gunter, 2006). Responsiveness therefore also addresses perishability, and is a measure of the firm's accuracy and ability to consistently get the right product in the right place, at the right time. The wrong product, the wrong place, the wrong time, or any combination of these mistakes, risks not only the delivered product's fitness for further processing or use expiring, but also the loss of other perishable inputs sourced by the customer, particularly in situations where perishable inputs from multiple sources need to be combined quickly to make the product. It is for these reasons that the literature highlights both the relevance and prevalence of responsiveness as a key sustainability dimension in food supply chains (Molnar \& Gellynk, 2009; Trienekens et al., 2008; Aramyan et al., 2007; Persson \& Olhager, 2002). Accordingly, we propose three measures of responsiveness: the responsiveness in meeting the arranged lead times (i.e. right time), the responsiveness in delivering to the arranged point of sales (i.e. right location), and the responsiveness in delivering the product as ordered (i.e. correct type and quantity). Again, like flexibility, these measures are an important gauge for SMEs of their efforts to contribute directly to the waste and consumption reduction efforts of other members upstream in the supply chain, thereby helping to maximise sustainability throughout the chain.

The fourth category of sustainability measures, comprising five measures, concern product quality. Final product quality and the associated raw material quality are widely recognised and used as key sustainability performance criteria (Keeble et al, 2003; Aramyan et al., 2007; Trienekens et al., 2008). Angell \& Klassen (1999) argue that placing quality at the centre of 
operational strategy facilitates the implementation of a robust sustainability drive in the supply chain. It is likely to be for this reason that quality is being used by food chain actors to address consumers' environmental anxieties (Ilbery \& Maye, 2005). This is important because waste in the food chain is one of the biggest barriers to sustainability (Parfitt et al., 2010). Both consumer confidence in the quality and safety of food products at the end of the chain, and chain member confidence upstream in the chain are critical factors for reducing food waste (Vasileiou \& Morris, 2006), and hence for reducing consumption of energy and materials in the production process. Alongside quality of the firm's product, four other product quality-related sustainability measures hold particular significance in food chains for helping to reduce waste and resource consumption.

Product conservation time is an important determinant of final product quality. Product conservation time refers to the length of time a food product within the chain maintains the desired properties and characteristics before it starts to deteriorate and become unusable. It is analogous to product shelf life which is specific to packaged ready for consumption foods (Aramyan et al., 2007). Product conservation time is closely correlated with the amount of waste generated by actors in the food supply chain (Heller \& Keoleian, 2003), and is to some extent dependent on storage and delivery conditions. It is an important sustainability measure, because knowledge of a product's conservation time enables the firm, in collaboration with other actors in the food chain, to better plan the nature and timing of operations and delivery in order to avoid the conservation time being exceeded, and hence resource being wasted. Furthermore, improved product conservation time supports the flexibility sustainability measures as it affords the firm greater flexibility in delivering to extra points of sale and in extra volume orders. It is important to note however, that product conservation time and storage costs must be considered together given that bulk-cold storage can prolong product conservation, but can also consume high levels of energy (Coley et al., 2009).

A near mandatory requirement in food supply chains is food traceability (van der Vorst et al., 2001; van der Vorst et al., 2006). It is considered an essential sustainability measure because it serves a number of important roles in reducing food waste and hence resource consumption. Firstly, traceability culminates in the food chain being able (via the final product labelling) to provide confidence to the consumers about the food products' quality, origin and safety (Carter \& Rogers, 2008; Ilbery \& Maye, 2005). Secondly, it provides similar confidence to 
the firms within the chain at each successive value-adding stage. Thirdly, in the event that there is a food scare resulting from unexpected events (e.g. the discovery of tampering), immediate product recall is inevitably required, and traceability information is essential for a rapid response, for identification and isolation of the problem and for mitigation (Maloni \& Brown, 2006; Dabbene \& Gay, 2011). The sooner the root cause can be identified the sooner the processing of unusable (or potentially unusable) and hence un-saleable product can be halted, reducing waste and resource consumption. Traceability also has an important operational role, enabling chain members to map product flows within the chain which can then be re-engineered to help reduce resource consumption, notably resources consumed in delivery and distribution.

Recent advances in food packing technologies (Marsh \& Bugusu, 2007) have highlighted the significant potential for providing products which cost less and are more environmentallyfriendly (Handfield et al., 1997). In tandem, regulatory and/or consumer demands for recyclable or returnable packaging and for clearer information on the nutritional and dietary characteristics of the food products (Maloni \& Brown, 2006) has heightened the importance of the need for packaging of good quality (Angell \& Klassen, 1999). As with traceability, good quality packaging provides consumer confidence in the quality of the food product (Vasiliou \& Morris, 2006). If advantageous - to improve flexibility for example - it can also extend product conservation time, and/or reduce the need for resource consumption in cold storage. As noted above, these factors can positively contribute to waste reduction. Not surprisingly, packaging in food supply chains is closely scrutinised and has become an important sustainability issue (Heller \& Keoleian, 2003). With 'total lifecycle' impact assessment increasingly prevalent (Lewis, 2005), packaging of good quality with enhanced labelling can positively contribute to reduced packaging waste (Carter \& Rogers, 2008), to the profitability of food supply chain members (Tracey et al., 2005), and hence to the opportunity for SMEs to re-invest in the aforementioned technologies or other sustainability measures.

To the preceding 16 food supply chain sustainability measures, we have added two complementary measures informed by the studies of Aramyan et al., (2007) and Carter \& Rogers (2008) which constitute the fifth performance category of our analysis. These recognise explicitly the importance of the chain members' own evaluation of their overall performance as a contributor to the sustainability of the food supply chain, and also the members' own evaluation of the possible external market's opinion of that performance. The 
latter is particularly salient as it is a gauge of consumer confidence in the food products and therefore has reputational implications and consequences (Carter \& Rodgers, 2008) to the firm's longevity and sustainability.

\section{Methodology}

To address the research questions, we employed 18 single item sustainable performance measures which we evaluated for individual members of the supply chain as well as the chain as a whole. We chose to employ single item measures due to their simplicity, brevity and global measurement (Fuchs \& Diamantopoulos, 2009). Also, we were only interested in a general measure of each performance element and hence asked the respondents to provide an overall perception, judgment or impression about the element of inquiry (Poon et al., 2002) and we avoided a lengthy questionnaire. In this way, we aimed to highlight the chain members that over-perform and underperform in each sustainable performance measure and the areas where the whole food chain needs to improve.

The firms that were eligible to participate in this research were identified through relevant directories such as the ICAP Business Directory (ICAP, 2007: a, b, c) and our sample covered a representative number of firms from both the various supply chain stages and the sectors involved. Initially we contacted each firm by telephone to identify the potential respondents "key informants". As we were focusing on SMEs, the appropriate "key informant" was normally the general manager or the owner of the firm who was deemed appropriate to answer our questionnaire due to their expert knowledge of the sustainable food chain performance of their organizations. By following this approach, the quality of responses was improved (Fynes et al., 2005).

The research initially employed a semi-structured interview that facilitated the questionnaire design (Subsection 3.1). This was followed by a pilot study of the questionnaire (Subsection 3.2) whilst the final questionnaire supported our data collection (Subsection 3.3).

\subsection{Semi-structured interview facilitating the questionnaire design}

The questionnaire was pre-tested through a qualitative stage where we employed a semistructured questionnaire in a satisfactory sample of qualitative interviews with senior supply chain practitioners and academics. Six senior academics were selected for the questionnaire 
pre-testing process and that selection was made based on their academic expertise.

Subsequently, they all had significant expertise in the field of supply chain management and they had detailed knowledge of the food sector and of SMEs. Similarly, five supply chain management practitioners who had relevant knowledge of the food sector and had significant experience working with SMEs were deemed appropriate respondents for the qualitative interviews. As our work focused on the major product categories (i.e. dairy, fruit, meat, vegetables) of the Greek food supply chain, we also aimed to select individuals who command a good knowledge of most of these product categories. Our questions focused on the five categories of supply chain sustainability measures (i.e. consumption, flexibility, responsiveness, quality and total supply chain performance) aiming to confirm their relevancy in measuring sustainability in SMEs in the food supply chain. Comments were prompted in relation to these measures based on our literature review and we followed a free-flowing line of questioning (Scott et al., 2013). Appendix A presents the semi-structured interview guide, its key topics and relevant questions that were discussed with respondents. Based on comments and feedback received during the qualitative interviews, we created the final list of the 18 measures. These were deemed as the most appropriate for measuring sustainability performance for SMEs in the Greek food chain. This pre-testing resulted in specific suggestions being provided and the refinement of the final questionnaire. The practitioners and academics who participated in the qualitative stage did not take part in the quantitative stage of this work.

\subsection{Structured questionnaire: Pilot study}

The questionnaire was also piloted in a sample of 36 SMEs from the Greek food supply chain. This sample aimed to represent successfully the examined supply chain stages (role or tier) and the three SME categories. Therefore, the pilot test was conducted with nine growers, nine manufacturers, nine wholesalers and nine retailers. We also included three firms per chain stage for every firm size under examination (e.g. three micro, three small and three mediumsized firms). In addition, in each chain stage, we guaranteed that at least two firms (out of nine) were dealing with dairy, fruit, meat or vegetable products. Therefore, the sample of the pilot test covered all potential sub groups of the food supply chain firms according to the chain stage, the SMEs category and the examined food product. These 36 firms were excluded from the final sample and their responses were excluded from our analysis. The results of the pilot test helped us to refine the questionnaire and to improve its wording. 


\subsection{Data collection employing the final questionnaire}

We employed a structured questionnaire survey to empirically validate our supply chain performance model. Survey was very appropriate for this type of research and has been frequently used in the past for performance evaluation in a supply chain (Islam \& Karim, 2011; Fantazy et al., 2009; Molnar \& Gellynk, 2009; Chow et al., 2008; Lai et al., 2004). The questionnaire was divided in two sections. The first section included questions on the five performance categories (consumption, flexibility, responsiveness, quality and total supply chain) and, as was discussed in Section 2, we adopted and adapted the measurement items from the studies reported in the third column of Table 1 ("source of measures"). Consumption measures were assessed in terms of the percentage of the firm's total turnover while the remaining measures were evaluated on a seven point Likert scale $(1=$ Extremely satisfactory performance; 2 = Quite satisfactory performance; $3=$ Slightly satisfactory performance; $4=$ Neither satisfactory nor unsatisfactory performance; $5=$ Slightly unsatisfactory performance; $6=$ Quite unsatisfactory performance; $7=$ Extremely unsatisfactory performance). The second section included questions on demographic representation in order to analyse the differences in performance with respect to the size of the firms.

The final quantitative data collection stage focused on the key supply chain members (breeders / growers / grower associations [hereafter referred to as growers], manufacturers, wholesalers / importers / exporters [hereafter referred to as wholesalers] and retailers) of the Greek food chain in relation to firm size. It is worth stressing that many changes have taken place in this food chain during the past two decades including the advent of many international manufacturers and retailers, the significant investment in logistics infrastructure (such as developing warehouses and using composite / multi-temperature distribution) by the major retail multiples, the use of sophisticated systems for various purposes (e.g. traceability and inventory management) and the increased popularity of own brand (private label) products (Bourlakis \& Bourlakis, 2001; Bourlakis et al. 2012). The latter has resulted in an increase of retail power which follows a similar trend across the globe.

Data collection was carried out by a professional research agency by means of a ComputerAided Personal Interviewing system and we only solicited one response from each firm sampled in the survey. Questionnaires were answered through telephone surveys representing every Greek region. It is useful to stress that a contact by telephone can improve the response rate as it allows the researcher to introduce the study to participants, to identify the right "key 
informants" and to arrange a time to conduct the survey based on their availability (Kopczak, 1997).

On many occasions, these "key informants" suggested other SMEs who might be interested to participate in our work and, they also suggested other SMEs with whom they were collaborating. As a result, the initial sampling frame included 2,950 members. 1,024 questionnaires were answered but 27 responses were not usable due to significant amounts of missing data. Subsequently, we analysed 997 responses representing micro, small and medium-sized firms and where both the number of full time employees and annual turnover were considered for determination of the size of firms in line with the EU's definition.

Overall, in these 997 responses, the "key informants" indicated their perceptions in relation to the sustainability performance measures examined. Here, it is worth acknowledging that any self-reported, perceptual measure can be subject to bias. But when there is no objective data or there is a major difficulty to obtain them (e.g. due to commercial sensitivity in our case), then expert judgments reveal important insights into the problem at hand. Similar methods were followed by several past studies (Tan et al., 2002; Gunasekaran et al., 2001). Finally, we employed analysis of variance (ANOVA) to determine whether the chain members have significant differences with respect to the 18 performance measures. ANOVA is a widely used statistical method for investigating significant statistical differences in performance and many examples can be found in the supply chain literature (Greer \& Ford, 2009; Kahn et al., 2006; Lai et al., 2004).

\section{Empirical Findings}

In Table 2, we provide a profile summary of respondents based on their position in the firm (i.e. general manager, marketing manager, owner, sales manager, trade manager and other) and the corresponding firm size (micro, small and medium-sized). 
Table 2 Profile summary of respondents

Firm size category

\begin{tabular}{lllllll}
\hline & \multicolumn{2}{c}{ Micro } & \multicolumn{2}{c}{ Small } & \multicolumn{2}{c}{ Medium } \\
\cline { 2 - 7 } Position in the company & Frequency & $\mathbf{( \% )}$ & Frequency & $\mathbf{( \% )}$ & Frequency & $\mathbf{( \% )}$ \\
\hline General Manager & 207 & $35.02 \%$ & 148 & $46.39 \%$ & 2 & $2.30 \%$ \\
\hline Marketing Manager & - & - & 4 & $1.26 \%$ & 18 & $20.69 \%$ \\
\hline Owner & 362 & $61.25 \%$ & 86 & $26.96 \%$ & - & - \\
\hline Sales Manager & - & - & 27 & $8.46 \%$ & 24 & $27.59 \%$ \\
\hline Trade Manager & 3 & $0.52 \%$ & 43 & $13.48 \%$ & 33 & $37.93 \%$ \\
\hline Other & 19 & $3.21 \%$ & 11 & $3.45 \%$ & 10 & $11.49 \%$ \\
\hline Total & 591 & $100 \%$ & 319 & $100 \%$ & 87 & $100 \%$ \\
\hline
\end{tabular}

The majority of respondents for micro firms are owners whereas the majority of respondents for small firms are general managers; a more "balanced" representation of various positions is evident for medium-sized firms. Table 3 shows the number of firms in each key food supply chain stage (tier) and their size. Our sample included 591 micro (59\%), 319 small (32\%) and 87 medium-sized (9\%) firms in total. We have 164 firms classified as growers (16\%), 226 firms classified as manufacturers (23\%), 434 firms classified as wholesalers (44\%) and 173 firms classified as retailers (17\%), leading to 997 firms in total. The breeders and growers are family-based firms. The grower associations are operating with 28 employees on average whilst the rest of the chain members employ various numbers of employees, with retailers having the highest number of employees on average (89).

Table 3 Firms classified according to supply chain role and firm size

\begin{tabular}{llllll}
\hline & Growers & Manufacturers & Wholesalers & Retailers & Total \\
\hline Micro & 139 & 82 & 233 & 137 & 591 \\
\hline Small & 19 & 108 & 167 & 25 & 319 \\
\hline Medium & 6 & 36 & 34 & 11 & 87 \\
\hline Total & 164 & 226 & 434 & 173 & 997 \\
\hline
\end{tabular}

On average, the level of turnover is between $€ 500,000$ and $€ 1,000,000$ for the growers, manufacturers and wholesalers. For retailers, the average turnover is $€ 200,000-€ 500,000$. Grower associations have the biggest warehouses $\left(3587.45 \mathrm{~m}^{2}\right.$ on average) and retailers the smallest ( $609.59 \mathrm{~m}^{2}$ on average) and all of the firms surveyed in this research are using transportation vehicles (trucks) for their operations. The breeders / growers and the grower associations were grouped together as they showed similar behaviour regarding their supply chain role and performance. Breeders / growers and grower associations are considered as first tier suppliers as, we advocate that, suppliers providing to farmers other agricultural input (e.g. machinery, fertilisers, equipment etc.) are second tier suppliers. A similar perspective has 
been followed in many previous agri-food and supply chain management research papers (see for example, Blundel \& Hingley, 2001; Thakkar, et al., 2009).

\subsection{Firm size versus supply chain stage (members' role)}

One of the unique contributions of this research is that we analysed the performance differences among micro, small and medium-sized firms with respect to their supply chain stage / members' role (namely growers, manufacturers, wholesalers and retailers). We do not report the non-significant differences due to space limitations and in order to serve the purpose of the paper which is to find out size-related differences among SMEs. Hence, the following subsections focus on reporting the significant differences only, in terms of firm size in the ANOVA test (at 0.05 significance level, see also Appendix B for a detailed description of all differences) and where the best performer for each measure is emphasized in bold. Finally, we discuss the implications of the lack of significant differences between the micro, small and medium sized enterprises in the discussion section (Section 5).

\subsubsection{Growers}

The growers in the Greek food supply chain do not generally have processing operations, with the micro growers (and some small ones) serving primarily local markets. Table 4 reports significant differences in performance measures when growers' data is analysed using ANOVA. There are two statistically significant differences in the sustainable performance measures with respect to firm size for the growers. Small growers perform better in terms of flexibility in extra volume orders and consistency of traceability system and average scores indicate "very satisfactory" perception in terms of these two variables. There are no statistically significant differences in performance between micro firms and the total sample or between medium firms and the total sample in terms of flexibility in extra volume orders and consistency of traceability system.

Table 4 Differences between micro, small and medium-sized growers

\begin{tabular}{lllll}
\hline Performance Measure & $\begin{array}{l}\text { Micro } \\
(\mathbf{n = 1 3 9 )}\end{array}$ & $\begin{array}{l}\text { Small } \\
(\mathbf{n = 1 9 )}\end{array}$ & $\begin{array}{l}\text { Medium } \\
(\mathbf{n = 6})\end{array}$ & $\begin{array}{l}\text { Total } \\
(\mathbf{n = 1 6 4})\end{array}$ \\
& $3.26(2.02)$ & $\mathbf{1 . 9 5}(\mathbf{1 . 0 3})$ & $3.67(1.75)$ & $3.12(1.97)$ \\
\hline Flexibility in extra volume orders & $3.26(2.03)$ & $\mathbf{1 . 2 6}(\mathbf{0 . 5 6})$ & $1.50(0.84)$ & $2.35(1.93)$ \\
\hline Consistency of traceability system & $2.53(\mathbf{s e a n})$ \\
\hline
\end{tabular}

A possible explanation of these findings may relate to the fact that the micro growers do not have enough capacity (and flexibility) to cope with changes in orders as they produce small 
volumes. These firms have not developed their supply chain and they often do not have the time, resources or information (and flexibility) to deliver the requested extra volume orders (Morgan, 2004). Medium-sized firms on the other hand may be negatively impacted by their size in relation to flexibility because although they have larger capacity in comparison to micro and small firms, they usually deal with large, multiple retailers or wholesalers and their production capacity is not always sufficient to accommodate extra, large orders from these firms (see Blundel \& Hingley, 2001; Hingley, 2001). Specifically, Hingley (2001, p. 63) stresses that modern retailers favour working with large and medium-sized agri-food suppliers in their effort to rationalise their supply base and to achieve "supply chain economies and partnership gains". Traill \& Pitts (1998) analyse the U.K. mushroom supply chain and note that large retailers source this product predominantly from large and medium-sized producers. Overall, medium-sized suppliers tend to sell their produce to retailers and wholesalers notwithstanding that many of them could follow alternative, additional market routes selling their products to farmers' markets, manufacturers, food service companies and with the latter depending on the type of product and its characteristics (Bourlakis \& Weightman, 2004). In terms of the consistency of using a traceability system, micro firms are likely to be operating in local markets, in relatively short supply chains giving products to local firms or even selling directly to consumers under the "laikes" format (see Alamanos et al., 2013), the Greek equivalent of farmers' markets (Guthrie et al., 2006). We are also aware that nowadays many micro agri-food farmers / growers compete successfully in global markets by working closely with agricultural cooperatives and exporter associations (Hazell et al., 2010; Jraisat et al., 2013). Nevertheless, the vast majority of the micro farmers of our sample indicated that they have limited international ambitions and the local market presents their key selling priority. Due to the above reasons, these firms may be less likely to use consistent traceability systems. Conversely, small and medium-sized growers may be shipping greater distances serving large retailers and wholesalers concerned with traceability implementation. This may be the main reason underlying the better performance of small (and to some extent medium-sized) growers in comparison to micro growers.

\subsubsection{Manufacturers}

Following an ANOVA test for manufacturers (Table 5), we observed a successful performance of micro firms in terms of gross profit margin. These micro manufacturers sell primarily to local and regional retailers and wholesalers (see relevant work in the UK by Blundel \& 
Hingley, 2001). Hence, we can contend that these micro firms could enjoy lower distribution costs compared to small and medium-sized manufacturers which sell nationally. In addition, many of these micro firms manufacture usually niche products (see work by Blundel \& Hingley, 2001; Hooley \& Saunders, 1998). This niche production can be supported by a protection designation of origin or protected geographical indication status (see O'Reilly \& Haines (2004) for other national manufacturers possessing a regional, speciality product and forming SME marketing networks). These micro manufacturers are normally members of local micro-business networks which can be very supportive (see Phillipson et al., 2006) and could be a major countervailing force against various financial demands opposed by other local supply chain members such as local retailers (Amato \& Amato, 2009). Hence, we can argue that a micro manufacturer possessing a strong product and operating in a local / regional (and usually niche) market will also be in a good position to protect itself against retailers' extra financial demands (see Amato \& Amato, 2009; seminal work by Porter, 1974). Overall, the above points could provide a possible explanation for the larger gross profit margins exhibited by micro (and to some extent by small manufacturers too, see Table 5). On the contrary, medium-sized manufacturers distribute to larger national retailers and wholesalers and could therefore be facing higher financial demands. For the remaining performance measures exhibiting statistical significance, medium-sized firms outperform both small and micro manufacturers.

Table 5 Differences between micro, small and medium-sized manufacturers

\begin{tabular}{|c|c|c|c|c|}
\hline Performance Measure & $\begin{array}{l}\text { Micro } \\
(\mathrm{n}=82) \\
\text { Mean (std) }\end{array}$ & $\begin{array}{l}\text { Small } \\
(\mathrm{n}=108) \\
\text { Mean (std) }\end{array}$ & $\begin{array}{l}\text { Medium } \\
(\mathrm{n}=36) \\
\text { Mean (std) }\end{array}$ & $\begin{array}{l}\text { Total } \\
(n=226) \\
\text { Mean (std) }\end{array}$ \\
\hline Gross profit margin & $\begin{array}{l}12.05 \\
(10.58)\end{array}$ & $\begin{array}{l}11.26 \\
(10.77)\end{array}$ & $5.60(3.33)$ & $\begin{array}{l}10.56 \\
(10.02)\end{array}$ \\
\hline Flexibility in extra volume orders & $3.02(1.70)$ & $2.23(1.28)$ & $2.17(1.66)$ & $2.51(1.55)$ \\
\hline $\begin{array}{l}\text { Flexibility in delivering in extra points of } \\
\text { sales }\end{array}$ & $3.04(1.83)$ & $2.33(1.61)$ & $2.08(1.36)$ & $2.55(1.69)$ \\
\hline Quality of packaging & $2.21(1.64)$ & $1.85(1.41)$ & $1.44(0.77)$ & $1.92(1.44)$ \\
\hline $\begin{array}{l}\text { Firm's perception of its own supply chain } \\
\text { performance }\end{array}$ & $2.46(1.17)$ & $1.97(0.75)$ & $1.97(0.77)$ & $2.15(0.95)$ \\
\hline $\begin{array}{l}\text { Firm's perceptions of market opinion } \\
\text { regarding its supply chain performance }\end{array}$ & $2.37(1.18)$ & $1.98(0.89)$ & $1.97(0.97)$ & $2.12(1.03)$ \\
\hline
\end{tabular}

In comparison to growers, manufacturers are more likely to have operational systems in place and, therefore, they are more flexible to accommodate changes in customer volume orders and 
points of sales (see relevant work by Carlsson, 1991). Specifically, medium-sized manufacturers outperform micro (and small) manufacturers in most sustainability measures given in Table 5. This can be related to higher economies of scale achieved by these firms in various operations (see Thakkar et al., 2009) including packaging. In terms of the firm's perception of its own supply chain performance and the firm's perceptions of market opinion regarding its supply chain performance, micro manufacturers perform worse than small and medium-sized manufacturers. This is a reflection of their poor performance in flexibility in extra volume orders, flexibility in delivering to extra points of sales and quality of packaging. Micro manufacturers may be aware of their poor performance in these measures and they may have resource constraints as well as limited use of relevant systems and processes. Therefore, they are aware of their limitations. Equally, medium-sized manufacturers perform slightly better than small manufacturers (for these two measures - firm's perception of its own supply chain performance and the firm's perceptions of market opinion regarding its supply chain performance). These firms are possibly aware of their ability to attract higher economies of scale (and scope by manufacturing products in similar categories) in their operations.

\subsubsection{Wholesalers}

A similar analysis for wholesalers reveals that small firms perform better in most performance measures with the exception of quality of packaging (Table 6). Specifically, packaging in the food sector requires specific know-how (see Sonneveld, 2000) and medium-sized wholesalers may be able to have better access to the necessary resources (skilled personnel, funds, technology) than micro and small wholesalers.

Table 6 Differences between micro, small and medium-sized wholesalers

\begin{tabular}{lllll}
\hline Performance Measure & $\begin{array}{l}\text { Micro } \\
(\mathbf{n = 2 3 3 )} \\
\text { Mean }(\mathbf{s t d})\end{array}$ & $\begin{array}{l}\text { Small } \\
(\mathbf{n = 1 6 7 )} \\
\text { Mean }(\mathbf{s t d})\end{array}$ & $\begin{array}{l}\text { Medium } \\
(\mathbf{n = 3 4 )} \\
\text { Mean (std) }\end{array}$ & $\begin{array}{l}\text { Total } \\
(\mathbf{n = 4 3 4 )} \\
\text { Mean (std) }\end{array}$ \\
\hline $\begin{array}{l}\text { Consistency of traceability } \\
\text { system }\end{array}$ & $2.24(1.55)$ & $\mathbf{1 . 8 0}(\mathbf{1 . 3 1})$ & $2.03(1.82)$ & $2.05(1.50)$ \\
\hline Quality of packaging & $3.40(2.44)$ & $2.58(2.25)$ & $\mathbf{1 . 7 1 ( 1 . 1 9 )}$ & $2.95(2.35)$ \\
\hline $\begin{array}{l}\text { Firm's perception of its own } \\
\text { supply chain performance }\end{array}$ & $2.36(0.98)$ & $\mathbf{2 . 0 7 ( 0 . 8 4 )}$ & $2.47(1.40)$ & $2.26(0.98)$ \\
\hline $\begin{array}{l}\text { Firm's perceptions of market } \\
\text { opinion regarding its supply chain } \\
\text { performance }\end{array}$ & $2.31(1.14)$ & $\mathbf{2 . 0 8 ( 0 . 9 0 )}$ & $2.53(1.21)$ & $2.24(1.07)$ \\
\hline
\end{tabular}

Medium-sized wholesalers also serve more distant markets (compared to micro and small wholesalers) and, due to this longer distance, they need to have high quality packaging to 
preserve the food items during transportation (see Peri, 2006). At the same time, micro wholesalers are less inclined to have consistent traceability systems. This may be related to the fact that they serve primarily the local market. A similar finding was noted for micro growers. It may also be the outcome of the low profit margins that wholesalers generally command compared to other chain members (see Dawson, 2004; Martinez, 2002), making the use of traceability systems, which are quite expensive, possibly prohibitive. Equally, small wholesalers (and medium) are more inclined to achieve consistency in terms of traceability. In terms of the last performance measures, small wholesalers seem to perform slightly better in both (firm's perception of its own supply chain performance and the firm's perceptions of market opinion regarding its supply chain performance).

\subsubsection{Retailers}

Finally, the ANOVA test performed for retailers indicates that micro firms outperform small and medium-sized firms in terms of gross profit margin (Table 7). This can be explained by the fact that the micro retailers of our sample are generally operating in remote and distant areas and sometimes they have a monopoly by being the sole grocery retailer running the only food store (most likely a small store format) in a village. These micro retailers are most likely to be buying from local growers and local manufacturers and, over the years, they have nurtured long-term relationships with growers and manufacturers as can be expected by a local micro-business network (Phillipson et al., 2006). Naturally, these micro retailers were recommended by other supply chain members of our sample (especially by growers and to some extent by manufacturers) co-located within the same vicinity. Overall, by being part of this local micro-business network, these micro retailers may be able to obtain satisfactory product prices. Equally, small and medium-sized retailers of our sample had stores predominantly in semi-urban and urban areas. This is not surprising, as small and mediumsized retailers normally operate larger food retail store formats too (e.g. large supermarkets) which require a larger catchment area, higher density of population and large volume of product sales in order to be profitable and sustainable (see Langston et al., 1997). Mediumsized retailers' waste performance measure, which is the cost of waste as a percentage of turnover is much lower than the micro and small firms. Medium-sized retailers manage larger volumes of product than the micro and may perform better in terms of reducing waste by having implemented appropriate practices and processes and by achieving higher economies of scale too (Thakkar et al., 2009). This may be attributed to the significant correlations 
identified between the size of the company and the initiatives taken to improve environmental performance and quality management certifications acquired (Massoud et al., 2010). Our finding is also in line with the research by Ilomaki \& Melanen (2001) who note that firm size matters in relation to environmental issues in general and in relation to waste management in particular. They highlight that micro and small firms are not interested to the above due to “the entrepreneur's lack of time for environmental issues, secondly, the entrepreneur's lack of knowledge and thirdly, the minimal economic significance of environmental issues, particularly wastes, to the micro enterprises" (Ilomaki and Melanen, 2001, p. 215). Finally, small firms perform better in terms of flexibility in extra volume orders and responsiveness in delivery in terms of the ordered type of product (exact code, quality, etc.). A similar finding was noted for small growers in relation to the flexibility performance measure.

Table 7 Differences between micro, small and medium-sized retailers

\begin{tabular}{lllll}
\hline Performance Measure & $\begin{array}{l}\text { Micro } \\
(\mathbf{n = 1 3 7 )} \\
\text { Mean }(\mathbf{s t d})\end{array}$ & $\begin{array}{l}\text { Small } \\
(\mathbf{n = 2 5}) \\
\text { Mean }(\mathbf{s t d})\end{array}$ & $\begin{array}{l}\text { Medium } \\
(\mathbf{n = 1 1}) \\
\text { Mean }(\mathbf{s t d})\end{array}$ & $\begin{array}{l}\text { Total } \\
(\mathbf{n = 1 7 3}) \\
\text { Mean }(\mathbf{s t d})\end{array}$ \\
\hline Gross profit margin & $\begin{array}{l}\mathbf{1 4 . 8 1} \\
\mathbf{( 1 1 . 5 3 )}\end{array}$ & $5.67(5.28)$ & $5.44(3.64)$ & $\begin{array}{l}12.66 \\
(11.03)\end{array}$ \\
\hline Waste & $6.95(6.54)$ & $3.58(3.82)$ & $\mathbf{2 . 0 0}(\mathbf{1 . 8 0})$ & $5.95(6.13)$ \\
\hline Flexibility in extra volume orders & $2.80(1.57)$ & $\mathbf{1 . 8 0}(\mathbf{0 . 9 6})$ & $2.55(1.75)$ & $2.64(1.54)$ \\
\hline $\begin{array}{l}\text { Responsiveness in delivery in terms of } \\
\text { the ordered type of product (exact code, } \\
\text { quality, etc.) }\end{array}$ & $1.77(1.11)$ & $\mathbf{1 . 4 8 ( \mathbf { 0 . 6 5 } )}$ & $2.55(2.30)$ & $1.77(1.18)$ \\
\hline
\end{tabular}

\subsubsection{Greek Food Chain}

We also examined the differences between micro, small and medium-sized firms in the whole sample in order to expose the under- and over-performing firms. Similar to the preceding analysis, out of the 18 performance measures, we only report those where we observe significant differences in terms of firm size (at 0.05 significance level, see Table 8 ). The best performer for each measure is emphasized in bold. 
Table 8 Significant differences with respect to firm size (ANOVA test)

\begin{tabular}{|c|c|c|c|c|}
\hline $\begin{array}{l}\text { Performance } \\
\text { Measure }\end{array}$ & $\begin{array}{l}\text { Micro } \\
(n=591) \\
\text { Mean (ST D) }\end{array}$ & $\begin{array}{l}\text { Small } \\
(n=319) \\
\text { Mean (ST D) }\end{array}$ & $\begin{array}{l}\begin{array}{l}\text { Medium } \\
(\mathrm{n}=87)\end{array} \\
\text { Mean (ST D) }\end{array}$ & $\begin{array}{l}\text { Total }(\mathbf{n}=997) \\
\text { Mean }(\text { ST D })\end{array}$ \\
\hline $\begin{array}{l}\text { Production / } \\
\text { operational / } \\
\text { raw material } \\
\text { cost }\end{array}$ & $43.74(27.99)$ & $49.53(26.20)$ & $50.93(29.65)$ & $46.32(27.67)$ \\
\hline $\begin{array}{l}\text { Gross Profit } \\
\text { margin }\end{array}$ & $12.52(11.35)$ & $11.45(11.40)$ & $8.10(8.60)$ & $11.83(11.22)$ \\
\hline $\begin{array}{l}\text { Delivery and } \\
\text { distribution } \\
\text { cost }\end{array}$ & $6.55(6.70)$ & $8.40(7.05)$ & $5.61(6.99)$ & $7.07(6.90)$ \\
\hline $\begin{array}{l}\text { Flexibility in } \\
\text { extra volume } \\
\text { orders }\end{array}$ & $2.82(1.69)$ & $2.25(1.27)$ & $2.49(1.78)$ & $2.61(1.59)$ \\
\hline $\begin{array}{l}\text { Flexibility in } \\
\text { delivering in } \\
\text { extra points of } \\
\text { sales }\end{array}$ & $3.04(1.89)$ & $2.38(1.54)$ & $2.52(1.73)$ & $2.78(1.80)$ \\
\hline $\begin{array}{l}\text { Responsiveness } \\
\text { in delivery in } \\
\text { terms of } \\
\text { arranged point } \\
\text { of sale }\end{array}$ & $2.00(1.43)$ & $1.76(1.12)$ & $1.95(1.36)$ & $1.92(1.34)$ \\
\hline $\begin{array}{l}\text { Responsiveness } \\
\text { in delivery in } \\
\text { terms of the } \\
\text { ordered type of } \\
\text { product (exact } \\
\text { code, quality, } \\
\text { etc.) }\end{array}$ & $2.07(1.62)$ & $1.71(1.20)$ & $1.89(1.43)$ & $1.94(1.49)$ \\
\hline $\begin{array}{l}\text { Product } \\
\text { conservation } \\
\text { time }\end{array}$ & $3.59(2.15)$ & $3.16(2.00)$ & $3.32(2.21)$ & $3.43(2.11)$ \\
\hline $\begin{array}{l}\text { Consistency of } \\
\text { traceability } \\
\text { system }\end{array}$ & $2.35(1.80)$ & $1.84(1.42)$ & $1.75(1.47)$ & $2.14(1.68)$ \\
\hline $\begin{array}{l}\text { Storage and } \\
\text { delivery } \\
\text { conditions }\end{array}$ & $1.80(1.17)$ & $1.55(0.94)$ & $1.57(1.01)$ & $1.70(1.09)$ \\
\hline $\begin{array}{l}\text { Quality of } \\
\text { packaging }\end{array}$ & $3.35(2.43)$ & $2.36(2.05)$ & $1.84(1.58)$ & $2.90(2.32)$ \\
\hline $\begin{array}{l}\text { Firm's } \\
\text { perception of } \\
\text { its own supply } \\
\text { chain } \\
\text { performance }\end{array}$ & $2.41(1.12)$ & $2.06(0.81)$ & $2.24(1.13)$ & $2.28(1.04)$ \\
\hline Firm's & $2.34(1.15)$ & $2.09(0.90)$ & $2.24(1.09)$ & $2.25(1.08)$ \\
\hline
\end{tabular}




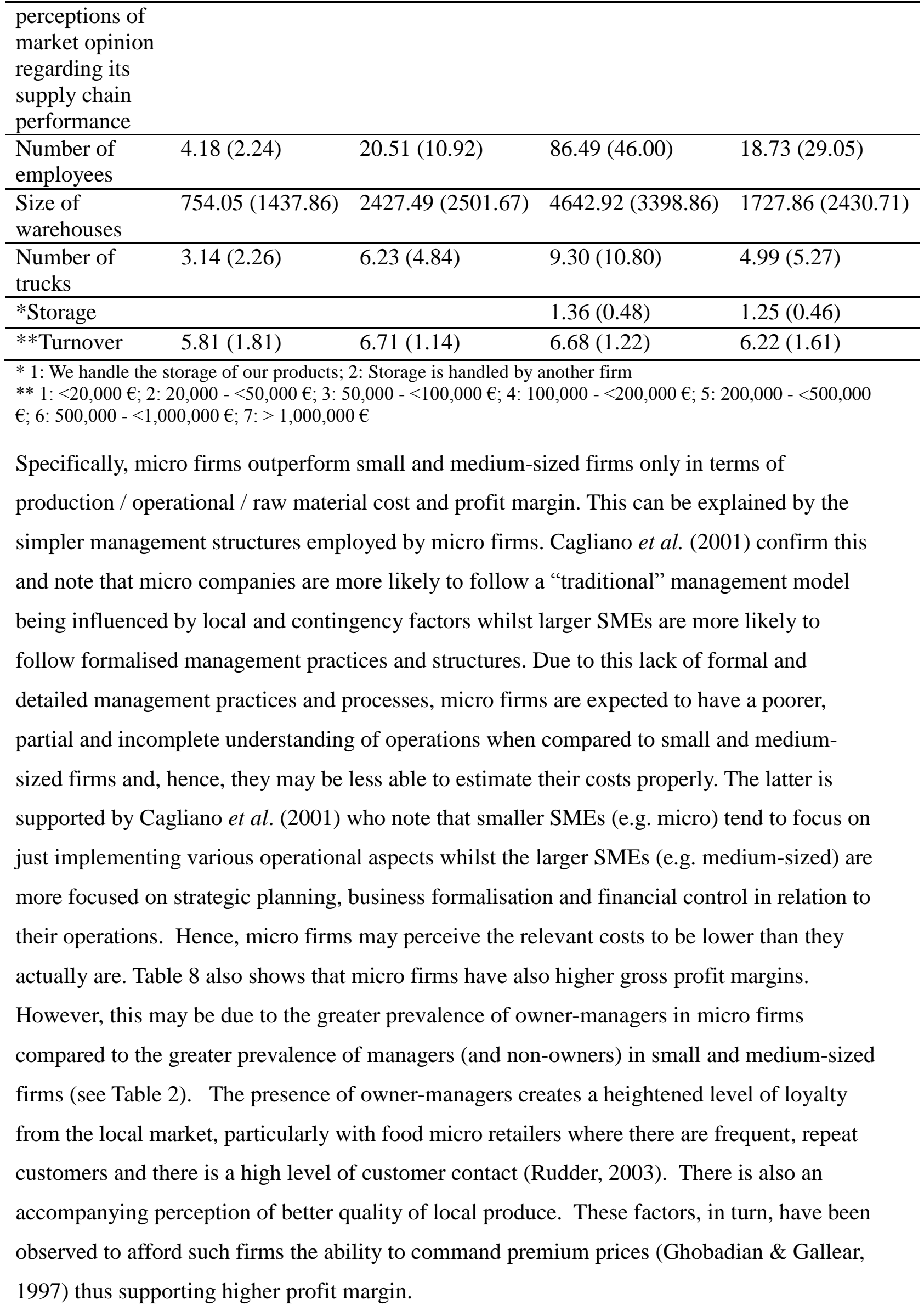


Medium-sized firms perform better in terms of delivery and distribution cost which may be due to the economies of scale enjoyed (Cagliano et al., 2001) and they also perform better in the consistency of traceability system and quality of packaging. This may be explained by increased knowledge and skills possessed by the greater number of people working in these firms as also noted by Cagliano et al. (2001). Small firms perform better in terms of the remaining measures. Specifically, they perform better for the responsiveness and flexibility measures (see Table 8). Small firms also outperform in terms of product conservation time but the score of this measure is alarming (a mean score of 3.16 for small firms and a mean score of 3.43 for all firms suggesting slightly satisfactory). We need to stress that product conservation time is affected by the highly perishable nature of food products (see Bogataj et al., 2005) and this is reflected as a challenge for the SMEs operating in the food chain. Particularly for micro firms, product conservation requires specific knowledge in applying the preservation technologies as well. Overall, product conservation time needs to be urgently improved for all firms as this poor score creates major concerns for product quality (see Peri, 2006) and subsequently supply chain, and consumer, safety (see Bogataj et al., 2005; Sahin et $a l .$, 2007). Another interesting difference relates to storage and delivery conditions where small firms outperform micro firms and perform slightly better than medium-sized firms. This may be due to high level of skills required especially for food products in terms of deliveries and storage where a cold chain needs to be maintained throughout (Bogataj et al., 2005); conversely, micro firms underperform in this measure.

In terms of overall perception of a firm's supply chain performance, small firms outperform. This is also the case with respect to perceptions of the market's opinion about the firms' performance. In terms of demographics of the firms, the average number of employees is 5 for micro firms, 21 employees for small firms and 87 employees for medium-sized firms (figures rounded up). The size of warehouses and number of trucks operated by the firms is consistent with the firm size. There is a significant difference between medium-sized firms and the sample average in terms of storage, where " 1 " indicated storage owned by the firm and " 2 " indicated storage outsourced. Turnover is also found to be consistent with firm size.

Finally, the previous findings highlighted a major concern, i.e. product conservation time. The latter merits further investigation and it provides an opportunity to cross-examine that measure (and others) between various product categories. Table 13 (Appendix B) summarises a range of sustainability performance measures where there are significant differences 
between SMEs dealing with fruit, dairy, meat and vegetable products. Specifically, in terms of product conservation time, there are significant differences between SMEs in the vegetable product category only where small firms perceive their performance higher than other firms. Likewise, there are significant differences between micro, small and medium-sized firms in terms of delivery and distribution cost in the dairy and vegetable product categories. For example, in the dairy category, the delivery and distribution cost is lower for micro firms and it is lower for medium-sized firms from the vegetable category. Additionally, there are differences in terms of flexibility in extra volume orders across all product categories and between micro, small and medium-sized firms. In terms of flexibility in delivering in extra points of sales, there are differences between micro, small and medium-sized firms representing fruit, dairy and meat products. Here, small firms from the fruit category perceive higher their performance compared to micro and medium-sized firms whereas medium-sized firms perceive their performance higher in the dairy and meat product categories. We also found differences between SMEs only in the dairy product category in connection with responsiveness in the arranged point of sale and responsiveness in delivery in terms of the ordered type of product. Here, small and medium-sized firms perceive their performance higher than that of micro firms. Differences were identified in consistency in using a traceability system and storage and delivery conditions in the dairy and vegetable product categories where medium-sized firms perceive their performance higher. Equally, mediumsized firms representing all examined product categories perceive their performance higher in relation to quality of packaging. Finally, there are significant differences between the SMEs representing the fruit, dairy and meat product categories in relation to firm's perception of its own supply chain performance. Here, small firms perceive their performance higher than others in fruit and meat product categories, and medium-sized firms perceive their performance higher in the dairy product category. In terms of firm's perceptions of market opinion regarding its supply chain performance, there is a difference only in the dairy product category where medium-sized firms perceive their performance higher. We are confident that the above analysis provides useful insights for the key differences between various firm sizes in connection with the examined food product categories.

\section{Discussion}

Most previous work has examined large firms versus SMEs (see Islam \& Karim, 2011) and when SMEs were examined, researchers tended to analyse SMEs from various industries (see 
Banomyong \& Supatn, 2011) or some categories were not included (see Koh et al. 2007 where micro firms were excluded from a performance measurement of SMEs). Equally, limited work has examined sustainability performance measurement in supply chains for SMEs (Gunther \& Kaulich, 2005; Lee et al., 2012) and none, according to our knowledge, in relation to SMEs in the food supply chains. Based on the above, we believe that our work has addressed this gap in the performance measurement literature (Bititci et al., 2012) by shedding light on the major sustainable performance differentials between all SME categories (micro, small and medium-sized firms) and by focusing at the same time on the same chain, the Greek food chain, an approach that has been recommended by Banomyong and Supatn (2011).

Specifically, in this paper, we conducted a comparative analysis of Greek food chain members in relation to firm size and illustrated their sustainable performance differences. This analysis highlighted that small growers, small wholesalers and small retailers exhibited better results in relation to numerous sustainability measures and only the medium-sized manufacturers performed better, albeit followed closely by small manufacturers in terms of performance. We believe that small growers, wholesalers and retailers could have benefitted from the locality parameter as they are members of a local micro-business network (Phillipson et al., 2006). For example, small growers have a guaranteed income by selling their products to local buyers (retailers and wholesalers). Equally, retailers and wholesalers serving their locality may have a monopoly or even oligopoly and may benefit from having developed long relationships with their local customers and suppliers (growers). Moreover, they have fewer costs by operating in rural areas and in smaller geographical areas (e.g. transport costs, labour costs). To our knowledge, this is a unique finding as no previous study has examined the role of locality in relation to sustainability performance measures by analysing separately local micro, small and medium food firms. Conversely, the medium-sized manufacturers seem to be the exception. This can be explained by the fact that manufacturing is an asset and resource intensive process where large economies of scale achieved by medium-sized manufacturers can result in heightened performance; the latter finding confirms previous research work (see for example, Carlsson, 1991; Thakkar et al., 2009). In addition, some patterns have emerged in terms of sustainability performance between these chain members. Specific medium-sized manufacturers and wholesalers perform better in relation to the "quality of packaging" measure. This can be attributed to the fact that these members may distribute products to national retailers and as they transport these products over large distances, they need to have 
more robust operations (Thakkar et al., 2009) including better and higher quality packaging. Another pattern emerging between these members relates to the locality parameter and the "consistency of traceability system" measure. For example, our analysis illustrated that micro growers and micro wholesalers which serve primarily the local market were underperforming in that measure. Our explanation is that these members may not be able to find a major commercial reason to implement these expensive systems as their priority is to serve their local, loyal and long standing customers (see for example, Alamanos et al., 2013); hence, they may be less inclined to implement traceability consistently. We believe that this is another unique finding as no previous work has demonstrated the role of size, for firms operating in a locality, in relation to implementation of traceability, a key sustainability performance measure. A final pattern is related to the "gross profit margin" measure and with micro manufacturers and retailers outperforming the rest of the chain members. This increased profit margin may be related to the locality parameter (e.g. local sourcing and selling) and the mode of operation. Micro retailers are likely to build strong relationships with their local customers (see Blundel \& Hingley, 2001) since the owner/manager of the firm is the face of the business, bringing a human aspect to the relationship. Micro manufacturers are also likely to produce niche and tailor made products to the local and regional market (e.g. with protection designation of origin status and protected geographical indication status) which also enjoy higher profit margins (see Amato \& Amato, 2009; Hooley \& Saunders, 1998). Hence, these findings demonstrate few key strategic paths which micro firms could follow. To our knowledge, the above findings also provide specific, original insights for the role of firm size in relation to the gross profit margin measure based on a unique cross-examination of the sustainability performance of various food supply chain members. The above address succinctly the first research question: How do micro, small and medium-sized members (growers, manufacturers, wholesalers, retailers) of the Greek food chain perform in key sustainability measures?

In terms of the second research question (Are there any differences in the sustainable performance of the Greek food chain with respect to firm size?), our analysis revealed a clear sustainability performance top performer, the small firms. This is an original finding considering the scarcity of research work examining firm size differences in relation to sustainability performance for food firms despite the fact that many authors have recommended research in that domain (see Bititci et al., 2012; Russo \& Tencati, 2009). Small firms excel in most sustainable performance measures and appear to be more flexible and 
responsive. This finding extends previous work by Cagliano et al. (2001, p. 474) who noted that "small companies perform highly on the practices associated with customer orientation" including flexibility and responsiveness to customer orders. Small firms also seem to excel compared to micro and medium-sized firms. For example, small firms seem to have the right number of employees (not a single owner operation as the micro firm), serve the right customer within the right reach (in the locality as noted earlier) and enjoy the right operational capacity to serve these customers and be flexible and responsive. Hence, these firms have manifested an ability to leverage "scalable supply chain management-related competences" resulting in the creation of a superior sustainable performance (Arend \& Wisner, 2005). On the other hand, micro firms perform better in the "Production / operational / raw material cost" and "Gross profit margin" measures. As mentioned earlier, we believe that the locality parameter may have an influential role to both measures as these firms source and sell primarily locally and manage products that are niche, hence, more profitable (see for example, Amato \& Amato, 2009; Blundel \& Hingley, 2001; Hooley \& Saunders, 1998). Therefore, we could argue that micro firms could be more sustainable as they operate fewer food miles and source locally as noted by Ilbery \& Maye (2005). Nevertheless, their poor performance in the rest of the measures (especially in "product conservation time", "quality of packaging" and "waste" [for micro retailers only, see Table 7]) does not permit us to make this argument. The medium-sized firms perform better in the "delivery and distribution cost", "quality of packaging" and "consistency of traceability system" measures. These are asset, resource and technical skills-intensive processes where medium-sized firms will benefit by achieving economies of scale and by having access to capital and people with the right skills (see for example, Carlsson, 1991; Thakkar et al., 2009). We also need to stress that these medium-sized firms sell nationally and sometimes they export their products to international markets and international retailers where "consistency of traceability system" is required (Hingley, 2001; Jraisat et al., 2013). Subsequently, they are more inclined to implement this measure. Overall, micro and small firms will be disadvantaged in terms of sustainability implementation, confirming relevant literature for this extra cost for acquiring these assets and skills (see Hassini et al., 2012) notwithstanding their limited availability of time, resources and information (see Vaaland \& Heide, 2007). In relation to "product conservation time", micro, small and medium-sized firms performed poorly. This finding is of major concern considering the negative repercussions for consumer health and product safety (see Bogataj et al., 2005; Peri, 2006; Sahin et al., 2007). Lastly, the final two measures (firm's perception of its own supply chain performance, firm's perceptions of market opinion 
regarding its supply chain performance) seem to reflect the findings for the other measures. This also validates our results as we have consistent, non-contradictory findings based on honest and accurate perceptions by the "key informants".

\section{Theoretical, managerial and policy implications}

Many theoretical implications emanate from this work. Specifically, Arend and Wisner (2005, p. 403) note that "conflict exists over how supply chain management affects small and medium-sized enterprises" and their work found that "SCM is not a good fit for SMEs on several performance measures" (ibid, p. 427). In this paper, we provide a more detailed and holistic perspective by identifying specific sustainability performance measures where SMEs excel and / or underperform. In the former scenario (SMEs' performance excelling), our results show a good fit between supply chain management and SMEs' sustainability performance. In that way, we extend the work by Arend and Wisner (2005) and advocate the critical role of supply chain management towards SMEs' operations. The latter is supported by Hong and Jeong (2006) who assert that an effective supply chain management is a key for delivering competitive advantage to SMEs. Overall, our work contributes largely to the above issue considering that researchers tend to ignore the role of logistics and supply chain management operations for SMEs (see Thakkar et al., 2009). In addition, Arend \& Wisner (2005, p. 406) stress "a lack of modification of the underlying SCM theories to account for the effects of firm size". Our paper addresses this point as we modify, and subsequently, test the relevant supply chain management and sustainability performance literature taking into account firm size. Subsequently, we show that micro, small and medium-sized firms enjoy different characteristics and they have a different outcome in relation to sustainability performance. Therefore, it is not advisable to treat all SMEs (micro, small and medium-sized) as one and "homogeneous" set of companies. Hence, the latter is a major contribution of our work as we found small firms excelling in most measures compared to micro and mediumsized firms. Focusing on the food supply chain context, our work has stressed a largely neglected dimension: the role of locality and local micro-business networks in relation to sustainability performance. We believe that food chain researchers should take into account the social structures and, especially, the local networks and relationships within which SMEs are part of (Phillipson et al., 2006) as these may have a critical role in relation to sustainability performance outcomes. Finally, our work develops and tests a plethora of sustainability performance measures in relation to food SMEs. This fills a major gap in the 
literature considering the absence of formal performance measurement systems (including sustainability ones) in the context of SMEs (see Bititci et al., 2012; Hong \& Jeong, 2006). More importantly, these measures are grouped under five elements (consumption, flexibility, responsiveness, quality, total supply chain) as we appreciate the interconnectedness and linkages that lie amongst them (see Thakkar et al., 2009).

In addition, this work has generated many implications for managers and policy makers. For example, managers for Greek micro firms need to be alert to the fact that their firms are underperforming in a range of measures and management action is required. Policy makers should also support these micro firms and identify ways to improve their sustainability performance. One possible remedy may be the use of e-business tools that can facilitate information exchange between supply chain members and could improve their performance in terms of, inter alia, responsiveness and flexibility especially when SMEs tend to make limited use of these tools (Levenburg, 2005). A major managerial and policy implication of this work relates to product conservation time. Managers need to prioritise the development of sufficient infrastructure and policymakers should provide relevant incentives to SMEs to undertake appropriate improvements in this measure (and any other measures where there is scope for improvement). Providing appropriate incentives and subsidies will be critical as most small firms view environmental measures expensive to undertake (Revell \& Blackburn, 2007). Overall, our work has highlighted a range of areas where improvement is required urgently. More importantly, we have developed a set of performance measures which can support managers of Greek SMEs in terms of prioritisation of their resources which are limited for SMEs.

Finally, we are confident that our work can be beneficial and applicable to other national contexts considering that 9 out of 10 SMEs are micro firms at European level (European Commission, 2005) and global levels (Worthington, 2012). Many countries share similar characteristics with Greece in relation to the role of SMEs within the food context too such as Southern European, Mediterranean and Middle East countries (see Alamanos et al., 2013; Bourlakis et al., 2012; Jraisat et al., 2013) notwithstanding that these characteristics can be relevant to most national contexts (see Small Business Act, 2012); hence, most of the aforementioned theoretical, managerial and policy implications can be applicable to a wider audience. For example, the role of locality (and local micro-business networks) for small firms in relation to sustainability performance can be equally relevant to other national 
contexts. Also, the role of locality for micro firms in relation to gross profit margin was highlighted in this paper and likewise it can be relevant to national environments. Product conservation time was found to be of major concern in this work and we are confident that similar result may be found elsewhere. Our work stressed the major differences in relation sustainability performance between the three SMEs' categories (micro, small, medium-sized) and we expect similar result to be prevalent elsewhere. Based on the above, we believe that our work can support managers, practitioners and policy makers located in other national environments.

\section{$7 \quad$ Conclusions}

Our work develops and tests a plethora of sustainability performance measures in supply chains in the context of food SMEs and fills a major gap in the literature considering the scarcity of relevant work (see Bititci et al., 2012; Gunther \& Kaulich, 2005; Lee et al., 2012). It also highlights the key differences between micro, small and medium-sized firms and, hence, it extends the current literature that focuses only on the differences between SMEs and large firms (see Ghobadian and Gallear, 1997; Sharma, 2004).

A limitation of this work is that we made use of specific measures examining a specific sector in a given national setting (Greek food chain). However, as was noted in the previous section, the generalisation of findings to other countries is applicable. The methodology followed uses single item measures to assess sustainable supply chain performance which made Cronbach's alpha coefficients non-applicable whilst any self-reported, perceptual measures collected from a single "key informant" might be causes for possible response bias. It should also be recognised that the amount of data required in the ANOVA test used in the research grows exponentially as the number of factors tested increases. Consequently, in our paper, firm size was considered as the single factor to check for the differences among SMEs. Future research could include multiple factors (e.g. firm size, chain role, type of product, markets served etc.) in the analyses if it is possible to collect data from larger samples. Future research could also include more, multiple item, sustainable performance measures which will be tested to other sectors and national environments. That research could include large organisations where their sustainability performance will be benchmarked against the SMEs. Similarly, future research could examine whether the heightened performance of small firms was the outcome of a deliberate or an emergent sustainability supply chain strategy (see Bourlakis \& Bourlakis, 2001). 


\section{References}

Alamanos, L., Bourlakis, M. \& Tzimitra-Kalogianni, I. 2013. Mediterranean diet and obesity: Consumers' attitudes towards tomato consumption in Greece, British Food Journal, 115(4), pp. 488-507.

Akkerman, R., Farahani, P., \& Grunow, M., 2010. Quality, safety and sustainability in food distribution: a review of quantitative operations management approaches and challenges. $O R$ Spectrum, 32(4), pp. 863-904.

Akyuz, G. A., \& Erkan, T. E., 2010. Supply chain performance measurement: a literature review. International Journal of Production Research, 48(17), pp. 5137-5155.

Amato, L.H. \& Amato, C.H., 2009. Changing retail power and performance in distribution channels. International Journal of Retail \& Distribution Management, 37(12), pp. 1057-1076.

Angell, L. C. \& Klassen, R. D., 1999. Integrating environmental issues into the mainstream: an agenda for research in operations management. Journal of Operations Management, 17(5), pp. 575-598.

Aramyan, L. H., Ondersteijn, C., van Kooten, O. \& Oude Lansink, A. G., 2006. Performance indicators in agri-food production chains. In: C. J. Ondersteijn, J. H. Wijnands, R. B. Huirne \& O. van Kooten, eds. Quantifying the Agri-food Supply Chain. Dordrecht: Springer, pp. 47 64.

Aramyan, L. H., van Kooten, O., van der Vorst, J. G. \& Oude Lansink, A. G., 2007. Performance measurement in agri-food supply chains: a case study. Supply Chain Management: An International Journal, 12(4), pp. 304-315.

Arend, R.J. \& Wisner, J.D., 2005. Small business and supply chain management: is there a fit?. Journal of Business Venturing, 20, pp.403-436.

Bai, C., Sarkis, J., Wei, X., \& Koh, L., 2012. Evaluating ecological sustainable performance measures for supply chain management. Supply Chain Management: An International Journal, 17(1), pp. 78-92.

Banomyong, R. \& Supatn, N., 2011. Developing a supply chain performance tool for SMEs in Thailand. Supply Chain Management: An International Journal, 16(1), pp. 20-31. 
Beamon, B., 1999. Measuring supply chain performance. International Journal of Operations and Production Management, 19(3-4), pp. 275-292.

Biondi, V., Frey, M., \& Araldo, F., 2000. Environmental management systems and SMEs. Motivations, opportunities and barriers related to EMAS and ISO 14001 implementation. Greener Management International, 29, pp. 55-69.

Bititci, U., Garengo, P., Dorfler, V. \& Nudurupati, S., 2012. Performance measurement: challenges for tomorrow. International Journal of Management Reviews, 14(3), pp. 305-327.

Blundel, R.K. \& Hingley, M.K., 2001. Exploring growth in vertical inter-firm relationships: Small-medium firms supplying multiple food retailers. Journal of Small Business and Enterprise Development, 8(3), pp. 245-265.

Bogataj, M., Bogataj, L. \& Vodopivec, R. 2005. Stability of perishable goods in cold logistic chains. International Journal of Production Economics, 93-94, pp. 345-356.

Bourlakis, M., Maglaras, G. \& Fotopoulos, C. 2012. Creating a "best value supply chain"? empirical evidence from the Greek food chain. International Journal of Logistics Management, 23(3), pp. 360-382.

Bourlakis, M. \& Weightman, P. (eds.), 2004. Food supply chain management, Blackwell Publications, Oxford.

Bourlakis, M. \& Bourlakis, C. 2001. Deliberate and emergent logistics strategies in food retailing: A case study of the Greek multiple food retail sector. Supply Chain Management: An International Journal, 6(4), pp. 189-200.

Brown, K. A., 1996. Workplace safety: a call for research. Journal of Operations Management, 14(2), pp. 157-161.

Cagliano, R., Blackmon, K. \& Voss, C., 2001. Small firms under MICROSCOPE: international differences in production / operations management practices and performance. Integrated Manufacturing Systems, 12(7), pp. 469-482.

Carlsson, B., 1991. The rise of small business: causes and consequences. Working Paper 357, The Industrial Institute for Economic and Social Research, Stockholm, Sweden, url: http://www.ifn.se/wfiles/wp/wp357.pdf date accessed: 03/06/2013 
Carter, C. R. \& Dresner, M., 2001. Environmental purchasing and supply management: crossfunctional development of grounded theory. Journal of Supply Chain Management, 37(3), pp. $12-27$.

Carter, C. R., Ellram, L. M. \& Tate, W. L., 2007. Structure and influence: a logistics management application of social network analysis. Journal of Business Logistics, 28(1), pp. 137-168.

Carter, C. R., Kale, R. \& Grimm, C. M., 2000. Environmental purchasing and firm performance: an empirical investigation. Transportation Research, Part E, 36(3), pp. 219-228.

Carter, C. R. \& Rogers, D. S., 2008. A framework of sustainable supply chain management: moving toward new theory. Journal of Physical Distribution and Logistics Management, 38(5), pp. 360-387.

Chan, F. \& Qi, H. J., 2003. An innovative performance measurement method for supply chain management. Supply Chain Management: An International Journal, 8(3-4), pp. 209-223.

Chow, W. S., Madu, C. N., Kuei , C. H. \& Tseng, H., 2008. Supply chain management in the US and Taiwan: An empirical study. Omega, 36(5), pp. 665-679.

Coley, D., Howard, M. \& Winter, M., 2009. Local food, food miles and carbon missions: a comparison of farm shop and mass distribution approaches. Food Policy, 34(2), pp. 150-155.

Cox, A., Chicksand, D. \& Palmer, M., 2007. Stairways to heaven or treadmills to oblivion? Creating sustainable strategies in red meat supply chains. British Food Journal, 109(9), pp. 689-720.

Dabenne, F. \& Gay, P., 2011. Food traceability systems: performance evaluation and optimization. Computers and Electronics in Agriculture, 75(1), pp. 139-146.

Dawson, J.A., 2004. Food retailing, wholesaling and catering. In: Bourlakis, M. \& Weightman, P. (eds.) Food supply chain management, Blackwell Publications, Oxford.

Dieu, T. T., 2006. Greening food processing industries in Vietnam: opportunities and constraints. Environment, Development and Sustainability, 8(2), pp. 229-249. 
Elgazzar, S. H., Tipi, N. S., Hubbard, N. J., \& Leach, D. Z., 2012. Linking supply chain processes' performance to a company's financial strategic objectives. European Journal of Operational Research, 223(1), pp. 276-289.

European Commission, 2005. The New SME Definition: User Guide and Model Declaration, Luxembourg: European Commission Publications Office.

Fantazy, K. A., Kumar, V. \& Kumar, U., 2009. An empirical study of the relationships among strategy, flexibility, and performance in the supply chain context. Supply Chain Management: An International Journal, 14(3), pp. 177-188.

Flint, D. J. \& Golicic, S. L., 2009. Searching for competitive advantage through sustainability. International Journal of Physical Distribution \& Logistics Management, 39(10), pp. 841-860.

Fuchs, C., \& Diamantopoulos, A., 2009. Using single-item measures for construct measurement in management research. Die Betriebswirtschaft, 69(2), 195.

Fynes, B., Voss, C. \& de Burca, S., 2005. The impact of supply chain relationship dynamics on manufacturing performance. International Journal of Operations and Production Management, 25(1), pp. 6-19.

Gadenne , D. L., Kennedy, J. \& McKeiver, C., 2008. An empirical study of environmental awareness and practices in SMEs. Journal of Business Ethics, 84(1), pp. 45-63.

Gerbens-Leenes, P. W., Moll, H. C. \& Uiterkamp, A. J., 2003. Design and development of a measuring method for environmental sustainability in food production systems. Ecological Economics, 46(2), pp. 231-248.

Ghobadian, A. \& Gallear, D., 1997. TQM and organization size. International Journal of Operations and Production Management, 17(2), pp. 121-163.

Gimenez, C., Sierra, V., \& Rodon, J., 2012. Sustainable operations: Their impact on the triple bottom line. International Journal of Production Economics, 140(1), 149-159.

Greer, B. \& Ford, M., 2009. Managing change in supply chains: A process comparison. Journal of Business Logistics, 30(2), pp. 47-63. 
Gunasekaran, A., Patel, C. \& McGaughey, R. E., 2004. A framework for supply chain performance measurement. International Journal of Production Economics, 87(3), pp. 333347.

Gunasekaran, A., Patel, C. \& Tirtiroglu, E., 2001. Performance measurement and metrics in a supply chain environment. International Journal of Operations \& Production Management, 21(1-2), pp. 71-87.

Gunther, E. \& Kaulich, S., 2005. The EPM-KOMPAS: an instrument to control the environmental performance in small and medium-sized enterprises (SMEs). Business Strategy and the Environment, 14(6), pp. 361-371.

Guthrie, J., Guthrie, A., Lawson, R. \& Cameron, A. 2006. Farmers' markets: the small business counter-revolution in food production and retailing. British Food Journal, 108(7), pp. 560-573.

Handfield, R. B., Walton, S. V., Seegers, L. K. \& Melnyk, S. A., 1997. 'Green' value chain practices in the furniture industry. Journal of Operations Management, 15(4), pp. 293-315.

Hassini, E., Surti, C. \& Searcy, C., 2012. A literature review and a case study of sustainable supply chains with a focus on metrics. International Journal of Production Economics, 140(1), pp. 69-82.

Hausman, A., 2005. Innovativeness among small businesses: Theory and propositions for future research. Industrial Marketing Management, 34(8), pp. 773-782.

Hazell, P., Poulton, C., Wiggins, S., \& Dorward, A., 2010. The future of small farms: Trajectories and policy priorities. World Development, 38(10), 1349-1361.

Heller, M. C. \& Keoleian, G. A., 2003. Assessing the sustainability of the US food system: a life cycle perspective. Agricultural Systems, 76(3), pp. 1007-1041.

Hingley, M., 2001. Relationship management in the supply chain. International Journal of Logistics Management, 12(2), pp. 57-71.

Hofmann, E. \& Locker, A., 2009. Value-based performance measurement in supply chains: a case study from the packaging industry. Production Planning \& Control, 20(1), pp. 68-81. 
Holmes, S. M., Power, M. L. \& Walter, C. K., 1996. A motor carrier wellness program: development and testing. Transportation Journal, 35(3), pp. 33-48.

Hong, P. \& Jeong, J., 2006. Supply chain management practices of SMEs: from a business growth perspective. Journal of Enterprise Information Management, 19(3), pp. 292-302.

Hooley, G.J. \& Saunders, J., 1998. Competitive positioning: The key to market success. Prentice-Hall, Hemel Hempstead.

Hudson , M., Smart, A. \& Bourne, M., 2001. Theory and practice in SME performance measurement systems. International Journal of Operation \& Production Management, 21(8), pp. 1096-1115.

ICAP Hellas, 2007a. The Greek canned fruit and vegetables sector. Athens: ICAP Hellas. ICAP Hellas, 2007b. The Greek dairy sector. Athens: ICAP Hellas.

ICAP Hellas, 2007c. The Greek meat sector. Athens: ICAP Hellas.

Ilbery, B. \& Maye, D., 2005. Food supply chains and sustainability: evidence from specialist food producers in the Scottish/English borders. Land Use Policy, 22(4), pp. 331-344.

Ilomaki, M. \& Melanen, M., 2001. Waste minimisation in small and medium-sized enterprises - do environmental management systems help? Journal of Cleaner Production, 9, pp. 209217.

Islam, M. \& Karim, A., 2011. Manufacturing practices and performance: Comparison among small-medium and large industries. International Journal of Quality \& Reliability Management, 28(1), pp. 43-61.

Jamsa, P., Tahtinen, J., Ryan, A. \& Pallari, M., 2011. Sustainable SMEs network utilization: the case of food enterprises. Journal of Small Business and Enterprise Development, 18(1), pp. 141-156.

Jraisat, L., Gotsi, M. \& Bourlakis, M. 2013. Drivers of information sharing and export performance in the Jordanian agri-food export supply chain: a qualitative study, International Marketing Review, 30(4), (in press). 
Kader, A. A., 2005. Increasing food availability by reducing postharvest losses of fresh produce. Acta Horticulturae, 682, pp. 2169-2175.

Kahn, K., Maltz , E. \& Mentzer, J., 2006. Demand collaboration: effects on knowledge creation, relationships, and supply chain performance. Journal of Business Logistics, 27(2), pp. 191-221.

Kaipia, R., Dukovska-Popovska, I., \& Loikkanen, L., 2013. Creating sustainable fresh food supply chains through waste reduction. International Journal of Physical Distribution \& Logistics Management 43(3), pp. 262-276.

Keeble, J. J., Topiol, S. \& Berkeley, S., 2003. Using indicators to measure sustainability performance at a corporate and project level. Journal of Business Ethics, 44(2), pp. 149-158.

Klassen , R. D. \& McLaughlin, C. P., 1996. The impact of environmental management on firm performance. Management Science, 42(8), pp. 1199-1214.

Klassen, R. D., \& Whybark, D. C., 1999. The Impact of Environmental Technologies on Manufacturing Performance. The Academy of Management Journal, 42(6), pp. 599-615.

Koh, S.C.L, Demirbag, M., Bayraktar, E., Tatoglu, E. \& Zaim, S., 2007. The impact of supply chain management practices on performance of SMEs. Industrial Management \& Data Systems, 107(1), pp.103-124.

Kolk, A., 2004. A decade of sustainability reporting: developments and significance. International Journal of Environment and Sustainable Development, 3(1), pp. 51-64.

Kopczak, L.R., 1997. Logistics partnerships and supply chain restructuring: survey results from the U.S. computer industry. Production and Operations Management, 6(3), pp. 226-247.

Kumar, S., \& Putnam, V., 2008. Cradle to cradle: Reverse logistics strategies and opportunities across three industry sectors. International Journal of Production Economics, 115(2), pp. 305-315.

Lai, K., Ngai, E. W. \& Cheng, T. C., 2004. An empirical study of supply chain performance in transport logistics. International Journal of Production Economics, 87(3), pp. 321-333. 
Lamprinopoulou, C. and Tregear, A., 2011. Inter-firm relations in SME clusters and the link to marketing performance, Journal of Business and Industrial Marketing, Vol. 26 No.6, pp. 421 $-429$.

Langston, P., Clarke, G.P. \& Clarke, D.B. 1997. Retail saturation, retail location, and retail competition: an analysis of British grocery retailing, Environment and Planning A, 29(1), pp. 77-104.

Lee, S. M., Kim, S. T. \& Choi, D., 2012. Green supply chain management and organizational performance. Industrial Management \& Data Systems, 112(8), pp. 1148-1180.

Levenburg, N.M., 2005. Does size matter? Small firm's use of e-business tools in the supply chain. Electronic Markets, 15(2), pp. 94-105.

Lewis, H., 2005. Defining product stewardship and sustainability in the Australian packaging industry. Environmental Science and Policy, 8(1), pp. 45-55.

Lohman , C., Fortuin, L. \& Vouters, M., 2004. Designing a performance measurement system: A case study. European Journal of Operational Research, 156(2), pp. 267-286.

Lundqvist, J., de Fraiture, C. \& Molden, D., 2008. Saving water: from field to fork-curbing losses and wastage in the food chain. In SIWI Policy Brief. Stockholm, Sweden: SIWI.

Ma, Z., \& Wang, S., 2010. a systematic optimization and operation of central chilling systems for energy efficiency and sustainability. Proceedings of Sixth International Conference on Improving Energy Efficiency in Commercial Buildings, 13-14 April Frankfurt, Germany.

Maloni, M. J. \& Brown, M. E., 2006. Corporate social responsibility in the supply chain: an application in the food industry. Journal of Business Ethics, 68(1), pp. 35-52.

Marsh, K. \& Bugusu, B., 2007. Food packaging-roles, materials, and environmental issues. Journal of Food Science, 72(3), pp. 39-55.

Martinez, S.W. 2002. Food wholesaling. In: Harris, J.M., Kaufman, P.R.., Martinez, S.W. \& Price, C. (eds.) The US food marketing system, 2002: competition, coordination and technological innovations into the $21^{\text {st }}$ century. USDA, Agricultural Economic Report No. 811, June. 
Massoud, M. A., Fayad, R., El-Fadel, M., \& Kamleh, R., 2010. Drivers, barriers and incentives to implementing environmental management systems in the food industry: A case of Lebanon. Journal of Cleaner Production, 18(3), 200-209.

McElroy, J. C., Rodriguez, J.M., Griffin, G.C., Morrow, P.C. \& Wilson, P.G., 1993. Career stage, time spent on the road, and truckload driver attitudes. Transportation Journal, 33(1), pp. 5-14.

Mintcheva, V., 2005. Indicators for environmental policy integration in the food supply chain (the case of the tomato ketchup supply chain and the integrated product policy). Journal of Cleaner Production, 13(7), pp. 717-731.

Molnar, A. \& Gellynk, X., 2009. Performance imbalances in the chain: EU traditional food sector. Proceedings of the 4th Aspects and Visions of Applied Economics and Informatics 2627 March Debrecen, Hungary, University of Debrecen.

Morgan, C., 2004. Structure, speed and salience: performance measurement in the supply chain. Business Process Management Journal, 10(5), pp. 522-536.

Moore, S. B., \& Manring, S. L., 2009. Strategy development in small and medium sized enterprises for sustainability and increased value creation. Journal of Cleaner Production, 17(2), pp. 276-282.

Moussis, N., 2013. Access to the European Union: Law, Economics, Policies, $20^{\text {th }}$ Ed. Intersentia Uitgevers $\mathrm{N}$ V.

Murray, J., Cawthorne, G., Dey, D., \& Andrew, C. (Eds), 2012. Enough for All Forever. Illinois: Common Ground.

Nieuwenhuis, P., Beresford, A., \& Choi, A. K-Y., 2012. Shipping or local production? $\mathrm{CO}_{2}$ impact of a strategic decision: An automotive industry case study. International Journal of Production Economics, 140(1), pp. 138-148.

Notta, O., Vlachvei, A. \& Samathrakis, V., 2010. Competitiveness - the case of Greek food manufacturing firms. International Journal of Arts and Sciences, 3(7), pp. 211-225. 
O’Reilly, S. \& Haines, M., 2004. Marketing quality food products - A comparison of two SME marketing networks. Food Economics - Acta Agriculturae Scandinavica, Section C, 1(3), pp. 137-150.

Parfitt, J., Barthel, M., \& Macnaughton, S., 2010. Food waste within food supply chains: quantification and potential for change to 2050. Philosophical Transactions of the Royal Society B, 365, pp. 3065-3081.

Peri, C. 2006. The universe of food quality. Food Quality \& Preference, 17(1-2), pp. 3-8.

Persson, F. \& Olhager, J., 2002. Performance simulation of supply chain designs. International Journal of Production Economics, 77(3), pp. 231-245.

Phillipson, J., Gorton, M., \& Laschewski, L., 2006. Local Business Co-operation and the Dilemmas of Collective Action: Rural Micro-business Networks in the North of England. Sociologia Ruralis, 46(1), 40-60.

Poon, W. Y., Leung, K., \& Lee, S. Y., 2002. The comparison of single item constructs by relative mean and relative variance. Organizational Research Methods, 5(3), 275-298.

Porter, M. E., 1974. Consumer behavior, retailer power and market performance in consumer goods industries. The Review of Economics and Statistics, 56(4), 419-436.

Porter, M. E., \& Kramer, M. R., 2006. Strategy and society - the link between competitive advantage and corporate social responsibility, Harvard Business Review, December, pp. 78-92.

Revell, A. \& Blackburn, R., 2007. The business case for sustainability? An examination of small firms in the UK's construction and restaurant sectors. Business Strategy and the Environment, 16(6), pp. 404-420.

Rogers, Z., Kelly, T. G., Rogers, D. S. \& Carter, C. R., 2007. Alternative fuels: are they achievable?, International Journal of Logistics: Research \& Application, 10(3), pp. 269-82.

Rudder, A., 2003. An evaluation of the NPD activities of four food manufacturers. British Food Journal, 105(7), 460-476. 
Russo, A. \& Tencati, A., 2009. Formal vs. informal CSR strategies: Evidence from Italian micro, small, medium-sized, and large Firms. Journal of Business Ethics, 85, pp. 339-353.

Sahin, E., Babai, M.Z., Dallery, Y. \& Vaillant, R. 2007. Ensuring supply chain safety through time temperature integrators. International Journal of Logistics Management, 18(1), pp. 102124.

Sanchez, A. M. \& Perez, M. P., 2005. Supply chain flexibility and firm performance: A conceptual model and empirical study in the automotive industry. International Journal of Operations \& Production Management, 25(7), pp. 681-700.

Sarkis, J., 2001. Manufacturing's role in corporate environmental sustainability. International Journal of Operations and Production Management, 21(5-6), pp. 666-686.

Scott, J. A., Ho, W., \& Dey, P. K. (2013). Strategic sourcing in the UK bioenergy industry. International Journal of Production Economics. Article in press. http://dx.doi.org/10.1016/j.ijpe.2013.01.027i

Seuring, S. \& Muller, M., 2008. From a literature review to a conceptual framework for sustainable supply chain management. Journal of Cleaner Production, 16(15), pp. 1699-1710.

Shepherd, C. \& Gunter, H., 2006. Measuring supply chain performance: current research and future directions. International Journal of Productivity and Performance Management, 55(34), pp. 242-258.

Sharma, P., 2004. An overview of the field of family business studies: Current status and directions for future research. Family Business Review, 17(1), pp. 1-36.

Shrivastava, P., 1995. Environmental technologies and competitive advantage. Strategic Management Journal, 16(3), pp. 183-200.

Small Business Act, 2012. SBA fact sheet for Greece, European Commission Enterprise and Industry, http://ec.europa.eu/enterprise/policies/sme/facts-figures-analysis/performancereview/files/countries-sheets/2012/greece_en.pdf, last accessed: 19 November, 2012.

Sonneveld, K. 2000. What drives (food) packaging innovation? Packaging Technology and Science, 13(1), pp. 29-35. 
Tan, K. C., Lyman , S. B. \& Wisner, J., 2002. Supply chain management: a strategic perspective. International Journal of Operations \& Production Management, 22(6), pp. 614631.

Thakkar, J., Kanda, A. \& Deshmukh, S.G. 2009. Supply chain management for SMEs: a research introduction. Management Research News, 32(10), pp. 970-993.

Theeranuphattana, A. \& Tang, J. C. S., 2008. A conceptual model of performance measurement for supply chains: Alternative considerations. Journal of Manufacturing Technology Management, 19(1), pp. 125-148.

Tracey, M., Lim, J. S. \& Vonderembse, M. A., 2005. The impact of supply-chain management capabilities on business performance. Supply Chain Management: An International Journal, 10(3), pp. 179-191.

Traill, W.B. \& Pitts, E. 1998. Competitiveness in the food industry. Blackie Academic, London.

Trienekens, J., van Uffelen, R., Debaire, J. \& Omta, O., 2008. Assessment of innovation and performance in the fruit chain: The innovation-performance matrix. British Food Journal, 110(1), pp. 98-127.

Vaaland, T. I. \& Heide, M., 2007. Can the SME survive the supply chain challenges?. Supply Chain Management: An International Journal, 12(1), pp. 20-31.

van der Vorst, J. G., 2006. Performance measurement in agri-food supply chain networks. An overview. In: C. J. Ondersteijn, J. H. Wijnands, R. B. Huirne \& O. van Kooten, eds. Quantifying the Agri-food Supply Chain. Dordrecht: Springer, pp. 13-24.

van der Vorst, J. G., van Dijk, S. J. \& Beulens, A. J., 2001. Supply chain design in the food industry. International Journal of Logistics Management, 12(2), pp. 73-85.

Vasileiou, K., \& Morris, J., 2006. The sustainability of the supply chain for fresh potatoes in Britain. Supply Chain Management: An international Journal, 11(4), pp. 317-327.

Wagner, B.A., Fillis, I. \& Johansson, U., 2003. E-business and e-supply in small and medium sized businesses, Supply Chain Management: An International Journal, 8(4), pp. 343-54. 
Worthington, I., 2012. Greening Business: Research, Theory, and Practice. London: Oxford University Press.

Wu, G-C., Ding, J-H., \& Chen, P-S., 2012. The effects of GSCM drivers and institutional pressures on GSCM practices in Taiwan's textile and apparel industry. International Journal of Production Economics, 135(2), pp. 618-636.

Wymenga, P., Spanikova, V., Barker, A., Konings, J. and Canton, E., 2012. EU SMEs in 2012: at the crossroads, Annual report on small and medium-sized enterprises in the EU, 2011/12, September, Rotterdam, the Netherlands, http://ec.europa.eu/enterprise/policies/sme/factsfigures-analysis/performance-review/files/supporting-documents/2012/annual-report_en.pdf, last accessed: 19 November 2012.

Zhu, Q. \& Sarkis, J., 2004. Relationships between operational practices and performance among early adopters of green supply chain management practices in Chinese manufacturing enterprises. Journal of Operations Management, 22(3), pp. 265-289.

Ziggers, G. W. \& Trienekens, J., 1999. Quality assurance in food and agribusiness supply chains: Developing successful partnerships. International Journal of Production Economics, Volume 60-61, pp. 271-279. 


\section{Appendix A: Research Methodology}

\subsection{Semi-structured interview questions}

Consumption: How relevant is supply chain consumption with sustainability in the food supply chain? What is your opinion about the following concerning sustainability in the food supply chain?

- Production / operational / raw materials cost

- Storage cost

- Delivery and distribution cost

- Waste

- Financial cost

- Gross profit margin

Flexibility: How relevant is supply chain flexibility with sustainability in the food supply chain? What is your opinion about the following concerning sustainability in the food supply chain?

- Flexibility in extra volume orders

- Flexibility in delivering in extra point of sales

Responsiveness: How relevant is supply chain responsiveness with sustainability in the food supply chain? What is your opinion about the following concerning sustainability in the food supply chain?

- Responsiveness in the arranged lead time

- Responsiveness in delivery in terms of arranged point of sale

- Responsiveness in delivery in terms of the ordered type of product (exact code, quality, etc.)

Quality: How relevant is quality in the supply chain with sustainability in the food supply chain? What is your opinion about the following concerning sustainability in the food supply chain?

- Quality of the firm's product

- Product conservation time

- Consistency of traceability system

- Storage and delivery conditions

- Quality of packaging

Overall supply chain performance: How relevant is quality in the supply chain with sustainability in the food supply chain? What is your opinion about the following concerning sustainability in the food supply chain?

- Firm's perception of its own supply chain performance

- Firm's perception of market opinion about its supply chain performance

Do you have any other comments with respect to sustainable supply chain performance in food supply chains? 


\subsection{The questionnaire}

Please report the following measures as a percentage of the firm's turnover:

\begin{tabular}{|l|l|l|}
\hline Q1 & Producing / operational / raw material cost as applicable & \\
\hline Q2 & Gross profit margin & \\
\hline Q3 & Storage cost & \\
\hline Q4 & Delivery and distribution cost & \\
\hline Q5 & Waste & \\
\hline Q6 & Financial cost & \\
\hline
\end{tabular}

Please indicate your level of satisfaction from the following measures for your firm where 1 = Very satisfactory; $2=$ Satisfactory; $3=$ Somewhat satisfactory; $4=$ Undecided $; 5=$ Somewhat unsatisfactory; $6=$ Unsatisfactory; $7=$ Very unsatisfactory

\begin{tabular}{|l|l|l|l|l|l|l|l|l|}
\hline Q7 & Flexibility in extra volume orders & 1 & 2 & 3 & 4 & 5 & 6 & 7 \\
\hline Q8 & Flexibility in delivering in extra points of sales & 1 & 2 & 3 & 4 & 5 & 6 & 7 \\
\hline Q9 & Responsiveness in the arranged lead time & 1 & 2 & 3 & 4 & 5 & 6 & 7 \\
\hline Q10 & Responsiveness in the arranged point of sale & 1 & 2 & 3 & 4 & 5 & 6 & 7 \\
\hline Q11 & $\begin{array}{l}\text { Responsiveness in delivery in terms of the ordered type of } \\
\text { product (exact code, quality, etc.) }\end{array}$ & 1 & 2 & 3 & 4 & 5 & 6 & 7 \\
\hline Q12 & Quality of the firm's product & 1 & 2 & 3 & 4 & 5 & 6 & 7 \\
\hline Q13 & Product conservation time & 1 & 2 & 3 & 4 & 5 & 6 & 7 \\
\hline Q14 & Consistency in using a traceability system & 1 & 2 & 3 & 4 & 5 & 6 & 7 \\
\hline Q15 & Storage and delivery conditions & 1 & 2 & 3 & 4 & 5 & 6 & 7 \\
\hline Q16 & Quality of packaging for firm's products & 1 & 2 & 3 & 4 & 5 & 6 & 7 \\
\hline Q17 & Firm's perception of its own supply chain performance & 1 & 2 & 3 & 4 & 5 & 6 & 7 \\
\hline Q18 & $\begin{array}{l}\text { Firm's perceptions of market opinion regarding its supply } \\
\text { chain performance }\end{array}$ & 1 & 2 & 3 & 4 & 5 & 6 & 7 \\
\hline
\end{tabular}

Please provide the following company - demographic information about your firm.

\begin{tabular}{|l|l|l|l|l|l|l|l|l|}
\hline Q19 & Number of employees & \multicolumn{6}{|c|}{$\mid$} \\
\hline Q20 & Turnover* & 1 & 2 & 3 & 4 & 5 & 6 & 7 \\
\hline
\end{tabular}

* 1: <€ 20.000; $2: € 20.001$ to $€ 50.000 ; 3: € 50.001$ to $€ 100.000 ; 4: € 100.001$ to

$€ 200.000 ; 5: € 200.001$ to $€ 500.000 ; 6: € 500.001$ to $€ 1.000 .000 ; 7:>€ 1.000 .001$ 
10 Appendix B: Empirical Findings on SMEs

\subsection{Growers}

Table 9 Descriptive statistics for micro, small and medium-sized growers

\begin{tabular}{|c|c|c|c|}
\hline Measure & Micro & Small & Medium \\
\hline $\begin{array}{l}\text { Producing / operational / raw material } \\
\text { cost }\end{array}$ & $47.55(26.37)$ & $44.53(24.63)$ & $37.5(17.68)$ \\
\hline Gross profit margin & $14.83(13.93)$ & $14.3(19.04)$ & $17(18.38)$ \\
\hline Storage cost & $5.33(7.16)$ & $8.8(15.68)$ & $10.5(13.44)$ \\
\hline Delivery and distribution cost & $5.79(6.91)$ & $6.4(6.11)$ & $\begin{array}{l}\text { Insufficient } \\
\text { data }\end{array}$ \\
\hline Waste & $5.95(7.21)$ & $5.27(6.08)$ & $5.5(0.71)$ \\
\hline Financial cost & $10.74(12.3)$ & $17.5(19.48)$ & $\begin{array}{l}\text { Insufficient } \\
\text { data }\end{array}$ \\
\hline Flexibility in extra volume orders & $3.26(2.02)$ & $1.95(1.03)$ & $3.67(1.75)$ \\
\hline $\begin{array}{l}\text { Flexibility in delivering extra points of } \\
\text { sales }\end{array}$ & $3.4(2.19)$ & $2.26(1.69)$ & $3.67(1.97)$ \\
\hline Responsiveness in the arranged lead time & $2.09(1.59)$ & $1.63(0.68)$ & $2.5(1.52)$ \\
\hline $\begin{array}{l}\text { Responsiveness in delivery in terms of } \\
\text { arranged point of sale }\end{array}$ & $2.24(1.81)$ & $1.79(1.4)$ & $2.5(1.52)$ \\
\hline $\begin{array}{l}\text { Responsiveness in delivery in terms of } \\
\text { the ordered type of product (exact code, } \\
\text { quality, etc.) }\end{array}$ & $1.98(1.42)$ & $1.74(0.99)$ & $2.5(1.38)$ \\
\hline Quality of the firm's product & $2.42(2.2)$ & $2.32(2.36)$ & $1.5(0.84)$ \\
\hline Product conservation time & $3.71(2.18)$ & $3.89(2.4)$ & $4(2.53)$ \\
\hline Consistency of traceability system & $2.53(2.03)$ & $1.26(0.56)$ & $1.5(0.84)$ \\
\hline Storage and delivery conditions & $1.83(1.14)$ & $1.74(1.19)$ & $1.33(0.82)$ \\
\hline Quality of packaging & $3.11(2.39)$ & $2.53(2.46)$ & $1.17(0.41)$ \\
\hline $\begin{array}{l}\text { Firm's perception of its own supply } \\
\text { chain performance }\end{array}$ & $2.45(1.16)$ & $2.26(0.73)$ & $3(0.63)$ \\
\hline $\begin{array}{l}\text { Firm's perceptions of market opinion } \\
\text { regarding its supply chain performance }\end{array}$ & $2.35(1.16)$ & $2.47(0.9)$ & $3(0.89)$ \\
\hline
\end{tabular}




\subsection{Manufacturer}

Table 10 Descriptive statistics for micro, small and medium-sized manufacturers

\begin{tabular}{llll}
\hline Measure & Micro & Small & Medium \\
\hline $\begin{array}{l}\text { Producing / operational / raw material } \\
\text { cost }\end{array}$ & $45.89(24.99)$ & $53.9(21.22)$ & $55.74(25.97)$ \\
\hline Gross profit margin & $12.05(10.58)$ & $11.26(10.77)$ & $5.6(3.33)$ \\
\hline Storage cost & $8.74(8.83)$ & $5.76(6.88)$ & $5.25(6.89)$ \\
\hline Delivery and distribution cost & $9.54(8.65)$ & $8.15(6.14)$ & $6.05(5.1)$ \\
\hline Waste & $6.27(7.03)$ & $6.47(7.97)$ & $3.71(5.14)$ \\
\hline Financial cost & $15.66(16.97)$ & $10.45(10.69)$ & $11.27(14.62)$ \\
\hline Flexibility in extra volume orders & $3.02(1.7)$ & $2.23(1.28)$ & $2.17(1.66)$ \\
\hline $\begin{array}{l}\text { Flexibility in delivering extra points of } \\
\text { sales }\end{array}$ & $3.04(1.83)$ & $2.33(1.61)$ & $2.08(1.36)$ \\
\hline Responsiveness in the arranged lead time & $1.74(1.04)$ & $1.62(0.89)$ & $1.64(0.9)$ \\
\hline $\begin{array}{l}\text { Responsiveness in delivery in terms of } \\
\text { arranged point of sale }\end{array}$ & $2.04(1.53)$ & $1.69(1.23)$ & $1.67(1.35)$ \\
\hline $\begin{array}{l}\text { Responsiveness in delivery in terms of } \\
\text { the ordered type of product (exact code, }\end{array}$ & & & \\
quality, etc.) & $1.71(1.02)$ & $1.62(0.97)$ & $1.44(0.61)$ \\
\hline Quality of the firm's product & $2.12(1.92)$ & $2.25(2.17)$ & $1.78(1.68)$ \\
\hline Product conservation time & $3.13(2.08)$ & $3.04(2.04)$ & $3.28(2.36)$ \\
\hline Consistency of traceability system & $2.04(1.64)$ & $1.87(1.52)$ & $1.53(1.25)$ \\
\hline $\begin{array}{l}\text { Storage and delivery conditions } \\
\text { Quality of packaging }\end{array}$ & $1.7(1.04)$ & $1.54(0.87)$ & $1.44(0.77)$ \\
\hline $\begin{array}{l}\text { Firm's perception of its own supply } \\
\text { chain performance }\end{array}$ & $2.21(1.64)$ & $1.85(1.41)$ & $1.44(0.77)$ \\
\hline $\begin{array}{l}\text { Firm's perceptions of market opinion } \\
\text { regarding its supply chain performance }\end{array}$ & $2.37(1.18)$ & $1.98(0.89)$ & $1.97(0.97)$ \\
\hline & & & \\
\hline
\end{tabular}




\subsection{Wholesalers}

Table 11 Descriptive statistics for micro, small and medium-sized wholesalers

\begin{tabular}{llll}
\hline Measure & Micro & Small & Medium \\
\hline $\begin{array}{l}\text { Producing / operational / raw material } \\
\text { cost }\end{array}$ & $39.69(29.38)$ & $46.15(28.23)$ & $47.07(32.78)$ \\
\hline Gross profit margin & $10.19(9.3)$ & $11.99(11.22)$ & $13.18(13.2)$ \\
\hline Storage cost & $6.6(6.81)$ & $6.97(7.24)$ & $6.46(8.03)$ \\
\hline Delivery and distribution cost & $7.24(6.23)$ & $9.08(7.69)$ & $7.54(10.49)$ \\
\hline Waste & $6.13(6.45)$ & $5.16(4.96)$ & $6.73(8.1)$ \\
\hline Financial cost & $9.51(11.26)$ & $9.59(10.42)$ & $13.54(14.69)$ \\
\hline Flexibility in extra volume orders & $2.49(1.45)$ & $2.36(1.31)$ & $2.62(1.88)$ \\
\hline $\begin{array}{l}\text { Flexibility in delivering extra points of } \\
\text { sales }\end{array}$ & $2.58(1.54)$ & $2.33(1.4)$ & $2.32(1.61)$ \\
\hline Responsiveness in the arranged lead time & $1.97(1.34)$ & $1.78(1.1)$ & $1.94(1.35)$ \\
\hline $\begin{array}{l}\text { Responsiveness in delivery in terms of } \\
\text { arranged point of sale }\end{array}$ & $1.92(1.4)$ & $1.64(0.98)$ & $1.88(1.37)$ \\
\hline $\begin{array}{l}\text { Responsiveness in delivery in terms of } \\
\text { the ordered type of product (exact code, } \\
\text { quality, etc.) }\end{array}$ & $1.82(1.1)$ & $1.73(1.05)$ & $1.85(1.21)$ \\
\hline Quality of the firm's product & $2.34(2.06)$ & $2.21(2.17)$ & $2.76(2.41)$ \\
\hline Product conservation time & $3.45(2.12)$ & $3.16(1.9)$ & $3.12(2.07)$ \\
\hline $\begin{array}{l}\text { Consistency of traceability system } \\
\text { Storage and delivery conditions }\end{array}$ & $2.24(1.55)$ & $1.8(1.31)$ & $2.03(1.82)$ \\
\hline Quality of packaging & $3.4(2.44)$ & $2.58(2.25)$ & $1.71(1.19)$ \\
\hline $\begin{array}{l}\text { Firm's perception of its own supply } \\
\text { chain performance }\end{array}$ & $2.36(0.98)$ & $2.07(0.84)$ & $2.47(1.4)$ \\
\hline $\begin{array}{l}\text { Firm's perceptions of market opinion } \\
\text { regarding its supply chain performance }\end{array}$ & $2.31(1.14)$ & $2.08(0.9)$ & $2.53(1.21)$ \\
\hline & & & \\
\hline
\end{tabular}




\subsection{Retailers}

Table 12 Descriptive statistics for micro, small and medium-sized retailers

\begin{tabular}{llll}
\hline Measure & Micro & Small & Medium \\
\hline $\begin{array}{l}\text { Producing / operational / raw material } \\
\text { cost }\end{array}$ & $45.36(28.63)$ & $57.58(32.69)$ & $46.71(39.17)$ \\
\hline Gross profit margin & $14.81(11.53)$ & $5.67(5.28)$ & $5.44(3.64)$ \\
\hline Storage cost & $4.77(7.2)$ & $3.8(5.35)$ & $3.38(4.14)$ \\
\hline Delivery and distribution cost & $4.21(5.08)$ & $6.09(6.63)$ & $2.11(3.33)$ \\
\hline Waste & $6.95(6.54)$ & $3.58(3.82)$ & $2(1.8)$ \\
\hline Financial cost & $5.28(7.03)$ & $5(4.67)$ & $2.63(3.29)$ \\
\hline Flexibility in extra volume orders & $2.8(1.57)$ & $1.8(0.96)$ & $2.55(1.75)$ \\
\hline $\begin{array}{l}\text { Flexibility in delivering extra points of } \\
\text { sales }\end{array}$ & $3.47(1.98)$ & $2.96(1.88)$ & $3.91(2.26)$ \\
\hline Responsiveness in the arranged lead time & $2.11(1.61)$ & $2.24(1.98)$ & $2.73(2.2)$ \\
\hline $\begin{array}{l}\text { Responsiveness in delivery in terms of } \\
\text { arranged point of sale }\end{array}$ & $2.15(1.78)$ & $2.16(1.99)$ & $2.27(1.85)$ \\
\hline $\begin{array}{l}\text { Responsiveness in delivery in terms of } \\
\text { the ordered type of product (exact code, } \\
\text { quality, etc.) }\end{array}$ & & & \\
\hline Quality of the firm's product & $1.77(1.11)$ & $1.48(0.65)$ & $2.55(2.3)$ \\
\hline Product conservation time & $3.96(2.16)$ & $3.16(2.13)$ & $3.73(2.15)$ \\
\hline Consistency of traceability system & $2.55(1.99)$ & $2.48(1.94)$ & $1.73(1.19)$ \\
\hline $\begin{array}{l}\text { Storage and delivery conditions } \\
\text { Quality of packaging }\end{array}$ & $1.88(1.2)$ & $1.56(0.65)$ & $1.55(0.93)$ \\
\hline $\begin{array}{l}\text { Firm's perception of its own supply } \\
\text { chain performance }\end{array}$ & $2.4(1.26)$ & $2.2(0.96)$ & $2(1.18)$ \\
\hline $\begin{array}{l}\text { Firm's perceptions of market opinion } \\
\text { regarding its supply chain performance }\end{array}$ & $2.35(1.17)$ & $2.32(0.85)$ & $1.82(0.75)$ \\
\hline & & & \\
\hline
\end{tabular}




\subsection{Greek food chain}

Table 13 Significant differences among SMEs for the food products

\begin{tabular}{|c|c|c|c|c|c|c|c|c|c|c|c|c|c|c|c|c|}
\hline & \multicolumn{4}{|c|}{ FRUIT } & \multicolumn{4}{|c|}{ DAIRY } & \multicolumn{4}{|c|}{ MEAT } & \multicolumn{4}{|c|}{ VEGETABLE } \\
\hline & $\begin{array}{l}\begin{array}{l}\text { Micro } \\
(\mathrm{n}=172\end{array} \\
\text { mean } \\
\text { (std) }\end{array}$ & $\begin{array}{l}\text { Small } \\
(\mathrm{n}=102) \\
\text { mean } \\
(\text { std })\end{array}$ & $\begin{array}{l}\text { Medium } \\
(\mathrm{n}=27) \\
\text { mean } \\
(\text { std })\end{array}$ & $\begin{array}{l}\text { Total } \\
(\mathrm{n}=301) \\
\text { mean } \\
(\text { std })\end{array}$ & $\begin{array}{l}\text { Micro } \\
(n=144) \\
\text { mean } \\
(\text { std) }\end{array}$ & $\begin{array}{l}\begin{array}{l}\text { Small } \\
(n=69)\end{array} \\
\text { mean } \\
(\text { std) }\end{array}$ & $\begin{array}{l}\text { Medium } \\
(n=13) \\
\text { mean } \\
\text { (std) }\end{array}$ & $\begin{array}{l}\text { Total } \\
(\mathrm{n}=226) \\
\text { mean } \\
(\text { std })\end{array}$ & $\begin{array}{l}\text { Micro } \\
(n=141) \\
\text { mean } \\
(\text { std })\end{array}$ & $\begin{array}{l}\begin{array}{l}\text { Small } \\
(\mathrm{n}=87)\end{array} \\
\text { mean } \\
\text { (std) }\end{array}$ & $\begin{array}{l}\text { Medium } \\
(\mathrm{n}=21) \\
\text { mean } \\
\text { (std) }\end{array}$ & $\begin{array}{l}\text { Total } \\
(\mathrm{n}=249) \\
\text { mean } \\
(\text { std })\end{array}$ & $\begin{array}{l}\text { Micro } \\
(n=134) \\
\text { mean } \\
(\text { std })\end{array}$ & $\begin{array}{l}\begin{array}{l}\text { Small } \\
(\mathrm{n}=61)\end{array} \\
\text { mean } \\
\text { (std) }\end{array}$ & $\begin{array}{l}\text { Medium } \\
(\mathrm{n}=26) \\
\text { mean } \\
\text { (std) }\end{array}$ & $\begin{array}{l}\text { Total } \\
(n=221) \\
\text { mean } \\
(\text { std })\end{array}$ \\
\hline Q4 & & & & & $\begin{array}{l}4.35 \\
(5.31)\end{array}$ & $\begin{array}{l}7.85 \\
(8.69)\end{array}$ & $\begin{array}{l}5.29 \\
(7.27)\end{array}$ & $\begin{array}{l}5.38 \\
(6.65)\end{array}$ & & & & & $\begin{array}{l}6.79 \\
(7.17)\end{array}$ & $\begin{array}{l}8.98 \\
(7.60)\end{array}$ & $\begin{array}{l}3.59 \\
(4.35)\end{array}$ & $\begin{array}{l}7.03 \\
(7.17)\end{array}$ \\
\hline Q7 & $\begin{array}{l}2.81 \\
(1.61)\end{array}$ & $\begin{array}{l}2.22 \\
(1.16)\end{array}$ & $\begin{array}{l}2.59 \\
(1.48)\end{array}$ & $\begin{array}{l}2.59 \\
(1.48)\end{array}$ & $\begin{array}{l}2.80 \\
(1.68)\end{array}$ & $\begin{array}{l}2.29 \\
(1.57)\end{array}$ & $\begin{array}{l}1.77 \\
(1.01)\end{array}$ & $\begin{array}{l}2.58 \\
(1.64)\end{array}$ & $\begin{array}{l}2.62 \\
(1.65)\end{array}$ & $\begin{array}{l}2.21 \\
(1.07)\end{array}$ & $\begin{array}{l}2.00 \\
(1.55)\end{array}$ & $\begin{array}{l}2.42 \\
(1.48)\end{array}$ & $\begin{array}{l}3.05 \\
(1.81)\end{array}$ & $\begin{array}{l}2.31 \\
(1.34)\end{array}$ & $\begin{array}{l}3.15 \\
(2.17)\end{array}$ & $\begin{array}{l}2.86 \\
(1.76)\end{array}$ \\
\hline Q8 & $\begin{array}{l}3.02 \\
(1.82)\end{array}$ & $\begin{array}{l}2.45 \\
(1.63)\end{array}$ & $\begin{array}{l}2.70 \\
(1.86)\end{array}$ & $\begin{array}{l}2.80 \\
(1.78)\end{array}$ & $\begin{array}{l}3.31 \\
(2.06)\end{array}$ & $\begin{array}{l}2.38 \\
(1.57)\end{array}$ & $\begin{array}{l}2.08 \\
(1.38)\end{array}$ & $\begin{array}{l}2.95 \\
(1.94)\end{array}$ & $\begin{array}{l}2.70 \\
(1.78)\end{array}$ & $\begin{array}{l}2.22 \\
(1.17)\end{array}$ & $\begin{array}{l}2.10 \\
(1.48)\end{array}$ & $\begin{array}{l}2.48 \\
(1.58)\end{array}$ & & & & \\
\hline Q10 & & & & & $\begin{array}{l}2.23 \\
(1.82)\end{array}$ & $\begin{array}{l}1.38 \\
(0.69)\end{array}$ & $\begin{array}{l}1.23 \\
(0.60)\end{array}$ & $\begin{array}{l}1.91 \\
(1.56)\end{array}$ & & & & & & & & \\
\hline Q11 & & & & & $\begin{array}{l}1.83 \\
(1.24)\end{array}$ & $\begin{array}{l}1.36 \\
(0.66)\end{array}$ & $\begin{array}{l}1.38 \\
(0.65)\end{array}$ & $\begin{array}{l}1.66 \\
(1.09)\end{array}$ & & & & & & & & \\
\hline Q13 & & & & & & & & & & & & & $\begin{array}{l}3.60 \\
(2.26) \\
\end{array}$ & $\begin{array}{l}2.66 \\
(2.00)\end{array}$ & $\begin{array}{l}3.23 \\
(2.27) \\
\end{array}$ & $\begin{array}{l}3.30 \\
(2.22) \\
\end{array}$ \\
\hline Q14 & & & & & $\begin{array}{l}2.27 \\
(1.84)\end{array}$ & $\begin{array}{l}1.81 \\
(1.15)\end{array}$ & $\begin{array}{l}1.23 \\
(0.44)\end{array}$ & $\begin{array}{l}2.07 \\
(1.70)\end{array}$ & & & & & $\begin{array}{l}2.51 \\
(1.90)\end{array}$ & $\begin{array}{l}1.57 \\
(1.15)\end{array}$ & $\begin{array}{l}1.46 \\
(0.81)\end{array}$ & $\begin{array}{l}2.13 \\
(1.69)\end{array}$ \\
\hline Q15 & & & & & $\begin{array}{l}1.72 \\
(1.17)\end{array}$ & $\begin{array}{l}1.35 \\
(0.59)\end{array}$ & $\begin{array}{l}1.23 \\
(0.44)\end{array}$ & $\begin{array}{l}1.58 \\
(1.01)\end{array}$ & & & & & $\begin{array}{l}1.99 \\
(1.36)\end{array}$ & $\begin{array}{l}1.61 \\
(0.97)\end{array}$ & $\begin{array}{l}1.38 \\
(0.85)\end{array}$ & $\begin{array}{l}1.81 \\
(1.23)\end{array}$ \\
\hline Q16 & $\begin{array}{l}3.45 \\
(2.44)\end{array}$ & $\begin{array}{l}2.49 \\
(2.01)\end{array}$ & $\begin{array}{l}1.56 \\
(0.80)\end{array}$ & $\begin{array}{l}2.96 \\
(2.28)\end{array}$ & $\begin{array}{l}3.01 \\
(2.31)\end{array}$ & $\begin{array}{l}2.07 \\
(1.75)\end{array}$ & $\begin{array}{l}1.38 \\
(0.65)\end{array}$ & $\begin{array}{l}2.63 \\
(2.15)\end{array}$ & $\begin{array}{l}3.57 \\
(2.51)\end{array}$ & $\begin{array}{l}2.31 \\
(1.98)\end{array}$ & $\begin{array}{l}2.10 \\
(1.81)\end{array}$ & $\begin{array}{l}3.01 \\
(2.36)\end{array}$ & $\begin{array}{l}3.34 \\
(2.31)\end{array}$ & $\begin{array}{l}2.56 \\
(2.37)\end{array}$ & $\begin{array}{l}2.15 \\
(2.19)\end{array}$ & $\begin{array}{l}2.98 \\
(2.35)\end{array}$ \\
\hline Q17 & $\begin{array}{l}2.50 \\
(1.15)\end{array}$ & $\begin{array}{l}2.08 \\
(0.78)\end{array}$ & $\begin{array}{l}2.56 \\
(1.09)\end{array}$ & $\begin{array}{l}2.36 \\
(1.05)\end{array}$ & $\begin{array}{l}2.31 \\
(1.05)\end{array}$ & $\begin{array}{l}1.96 \\
(0.79)\end{array}$ & $\begin{array}{l}1.62 \\
(0.65)\end{array}$ & $\begin{array}{l}2.16 \\
(0.98)\end{array}$ & $\begin{array}{l}2.34 \\
(1.08)\end{array}$ & $\begin{array}{l}1.93 \\
(0.71)\end{array}$ & $\begin{array}{l}2.24 \\
(0.77)\end{array}$ & $\begin{array}{l}2.19 \\
(0.96)\end{array}$ & & & & \\
\hline Q18 & & & & & $\begin{array}{l}2.33 \\
(1.10)\end{array}$ & $\begin{array}{l}1.91 \\
(0.78)\end{array}$ & $\begin{array}{l}1.69 \\
(0.63)\end{array}$ & $\begin{array}{l}2.16 \\
(1.01)\end{array}$ & & & & & & & & \\
\hline
\end{tabular}

Q4: Delivery and distribution cost; Q7: Flexibility in extra volume orders; Q8: Flexibility in delivering in extra points of sales;

Q10: Responsiveness in the arranged point of sale; Q11: Responsiveness in delivery in terms of the ordered type of product (exact code, quality, etc.);

Q13: Product conservation time; Q14: Consistency in using a traceability system; Q15: Storage and delivery conditions; Q16: Quality of packaging for firm's products;

Q17: Firm's perception of its own supply chain performance; Q18: Firm's perceptions of market opinion regarding its supply chain performance 